\title{
Life on a hilltop: vegetation history, plant husbandry and pastoralism at the dawn of Bergamo-Bergomum (northern Italy, 15th to 7th century $\mathrm{BC}$ )
}

\author{
Roberta Pini ${ }^{1}$ (D) Cesare Ravazzi ${ }^{1} \cdot$ Roberto Comolli $^{2} \cdot$ Renata Perego $^{1} \cdot$ Lorenzo Castellano $^{3} \cdot$ Camilla Croci $^{1}$. \\ Mattia De Amicis ${ }^{2}$. Davide Abu El Khair ${ }^{2} \cdot$ Giulia Furlanetto $^{1} \cdot$ Diego Marsetti $^{4}$
}

Received: 16 April 2020 / Accepted: 4 October 2020 / Published online: 2 November 2020

(c) Springer-Verlag GmbH Germany, part of Springer Nature 2020

\begin{abstract}
Cores and trenches drilled or dug in religious and secular buildings in the hilltop town of Bergamo (northern Italy) were investigated by means of micro/macrobotanical and pedochemical analysis to unravel the cultural vegetation history of the area during ca. seven centuries across the Bronze-Iron Ages. We explore the predictive power of biological proxies, nutrients, and coupled ${ }^{14} \mathrm{C}$ datings to reveal early phases of human settlement and activity in a modern urban context with low visibility and difficult accessibility. Our records suggest that a farming centre was active on the Bergamo hilltop as early as the 15th century BC. Crop and animal husbandry reached a high point between the 11th-8th century BC. Plant and biogeochemical proxies predict extensive and diversified cereal cropping, flax and grapevine cultivation, as well as herd stalling at a watering pond, free range livestock growing in woodlands, and pastoralism, shown by hay making and overgrazing evidence. The suggestive hypothesis of carding wool is mentioned but is currently untenable. Furthermore, we identified a possible phase of abandonment starting from the 8th century вс, to be further investigated, and in agreement with archaeological data suggesting settlement decline in the 8th-6th century $\mathrm{BC}$. Our research highlights the dedication to pastoralism of the Bergamo hill since prehistoric times. The settlement position was strategic for pastoralists to exploit biological and water resources in space, season and elevation, i.e. from the plain to higher Alpine pastures. Ethnographic examples and Middle Age written sources strongly support this picture.
\end{abstract}

Keywords Cultural vegetation history $\cdot$ Grassland ecology $\cdot$ Nutrients ecology $\cdot$ Hay meadows $\cdot$ Bronze-Iron Ages palaeoecology $\cdot$ Bergomum

Communicated by C.C. Bakels.

Electronic supplementary material The online version of this article (https://doi.org/10.1007/s00334-020-00802-1) contains supplementary material, which is available to authorized users.

Roberta Pini

roberta.pini@igag.cnr.it

1 Lab. of Palynology and Palaeoecology, CNR-IGAG, Research Group On Vegetation, Climate and Human Stratigraphy, Piazza della Scienza 1, 20126 Milano, Italy

2 Dept. of Environmental and Earth Sciences, University of Milano-Bicocca, Piazza della Scienza 1, 20126 Milano, Italy

3 Institute for the Study of the Ancient World, New York University, 15 East 84th Street, NY, USA

4 ECOGEO Srl, via Fratelli Calvi 2, 24122 Bergamo, Italy

\section{Introduction}

Archaeological records, including material artefacts and their contextual information, are used to trace back in time the history of humans and their activities (Lucas 2013). Discussion on these topics, so vivid in the archaeological community, is often biased by the lack of a proper palaeoenvironmental and economic dimension reconstructed through specific sets of methods (Stasky 1982).

The interplay between environmental and cultural development in the Bronze-Iron Age of the hills bordering the Alpine fringe in central Northern Italy (Fig. 1a) is still poorly known.

Areas where some of the main protourban centres developed between the 7th-5th century BC (Bergamo and Como: Casini et al. 2001; Poggiani Keller 2007a) have so far yielded limited palaeoecological information (Bergamo: 


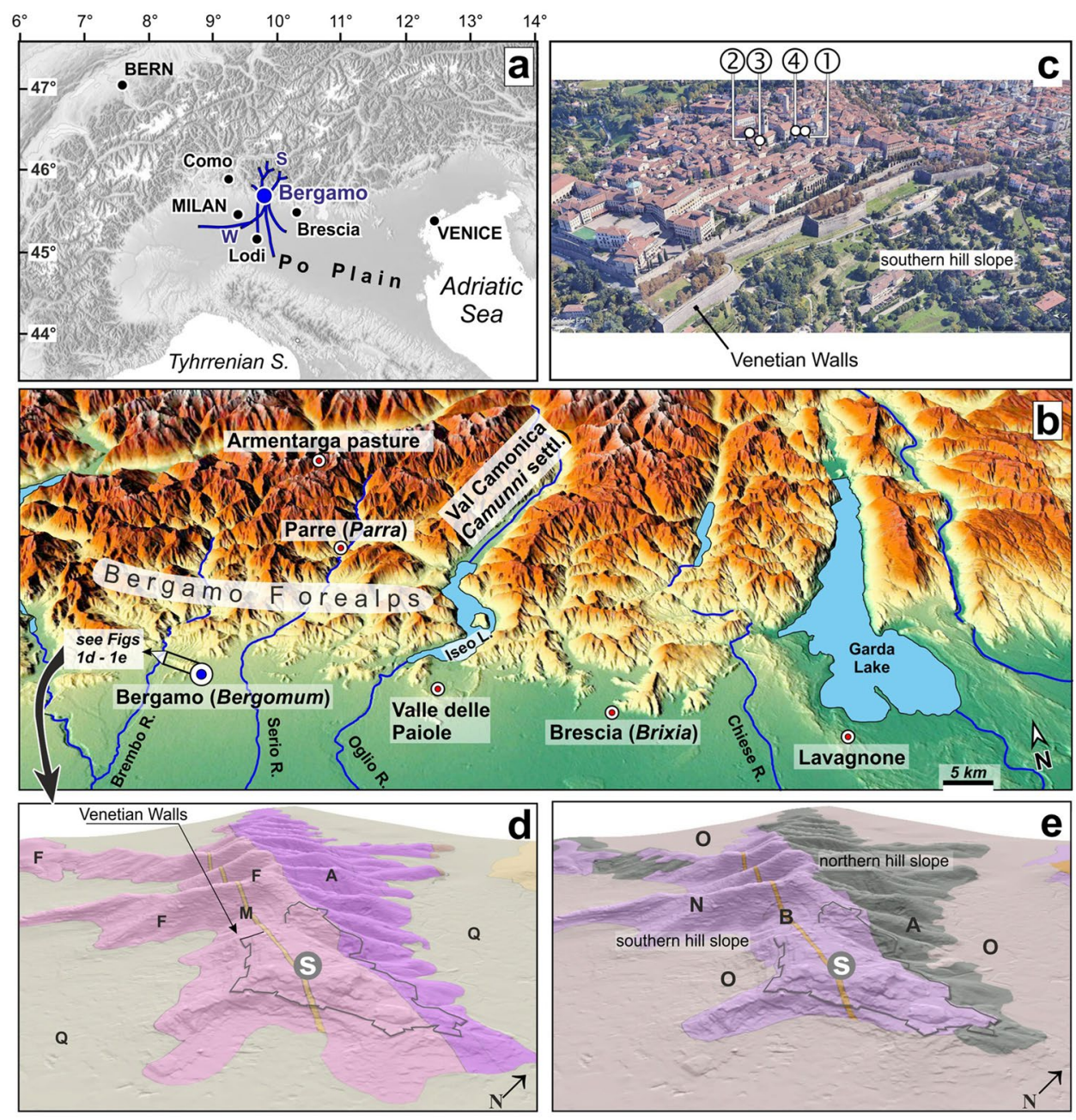

Fig. 1 a Location of Bergamo in N-Italy at the southern fringe of the Alps. Lines show the main transhumance paths across the town in the Late Middle Ages (according to Corti 2006; https://www.ruralpini.it/ Alpeggi_StoriaN.htm). W = areas of winter herding; $S=$ areas of summer herding. b Physical setting of the Italian Alpine border facing the Po Plain, also showing the pre-roman settlements mentioned in the text. c A view of the ancient city covering the Bergamo hilltop ("Città Alta") from SSW (from Google Earth) showing the location of the studied sites in the heart of the early settlement: 1 -Cathedral Main core; 2-Palazzo del Podestà core; 3-Domus dei Bragagnoli Trench C; 4-Cathedral Trench C. The Venetian Walls and the southern hill slope are shown. d 3D geological map of the Bergamo Hills, view from SSE (digital terrain model from Database Topografico

Pini et al. 2016; Como: Martinelli et al. 2017). The reason behind this is the lack of favoured stratigraphic archives, i.e. lakes or mires, which has prevented the development of palaeoecological studies in connection to archaeological contexts discovered in these areas. This paper represents the first step to fill this gap and lays the foundation for a research protocol to investigate the past from sedimentary archives preserved below modern cities.

Our research focuses on the hilltop town of Bergamo (northern Italy, Fig. 1a), a place with a long tradition of del Comune di Bergamo; geological layers simplified after Bersezio et al. 2012). The Venetian Walls surrounding the old city are outlined. Bedrock-F $=$ Flysch of Bergamo; $\mathrm{M}=$ Missaglia limestone seam; $\mathrm{A}=$ Sarnico Sandstone; $\mathrm{Q}=$ Quaternary cover, indistinct; (S) position of studied sites. e 3D map of most relevant soil features potentially affecting vegetation patterns in the pre-anthropic Bergamo Hills, i.e. reaction and saturation of the exchange complex. A=Acidic soils with low-saturated exchange complex; $\mathrm{N}=$ Neutral and sub-acidic soils, with high-saturated exchange complex; $\mathrm{B}=$ shallow basic Regosols with high-saturated exchange complex; $\mathrm{O}=$ Other soils, mostly marked by an aquic water capacity on the foothills, unsuitable for ploughing (elaboration based on Bonalumi et al. 1992; modified)

archaeological excavations (see 'The study area'). Recent research (Ravazzi et al. 2020) has provided a comprehensive view of the lithostratigraphy and sedimentology of two long cores and trenches from the heart of the city. Using a selection of palaeobotanical and pedochemical data, the authors depicted a rich framework for the stepped emergence of a prehistoric settlement on the Bergamo hilltop, with a farming centre active in the 15 th century BC. In this companion paper, we provide a thorough view of the botanical and pedochemical information yielded by those sediments, 
in order to reconstruct the history of vegetation and human activities on the Bergamo hilltop between the 15th-7th century BC. Multiproxy data depict the environmental frame prior to the process of urbanization, unravelling the past as a farming society of a later to be protourban centre. Plant ecological/taphonomical groups are recognized based on micro- and macrobotanical descriptors identified in sediments, and trace phases of contraction/expansion of natural forests, the development of animal and crop husbandry, and fire activity. The indicator value of selected plants identified by their fossil pollen or fruits, along with coprophilous fungi and intestinal parasites, is discussed to predict synanthropic habitats and specific land uses. Finally, the case study of the already emerging importance of pastoralism in the Final Bronze Age Bergamo will be located within the wider frame of Late Bronze-Iron Age economy and settlement strategy at the southern Alpine fringe through an analysis of the ethnographical parallelisms and written sources.

\section{The study area}

\section{A short introduction and archaeological background}

Bergamo is a large and wealthy city of Northern Italy (Fig. 1a), composed of two parts: (i) the historical old Upper Town (Città Alta) developed on the Bergamo Hill between 360-380 $\mathrm{m}$ a.s.l. and surrounded by massive defensive walls built during the Venetian Domination of the 16th-17th century AD. Since 2017 the Bergamo walls have been listed as a UNESCO World Heritage serial and transnational site; (ii) the modern Lower Town (Città Bassa) largely developed on the plain and connected to the old town by a funicular railway and roads. The research presented in this paper is set in the historical Upper Town of Bergamo.

Neolithic and Copper Age villages, and a Bronze Age pile dwelling are documented in the foothills (Poggiani Keller and Rondini 2019). Sporadic findings document human frequentation of the Bergamo Hill between the 5th-2nd millennia BC. Ceramic fragments brought to light in the Cathedral trench $\mathrm{C}$ excavation (site 4 in Fig. 1c) point to the presence of a settlement on the Hilltop of Bergamo during the Final Bronze Age (Poggiani Keller and Rondini 2019). The bedding of these finds needs to be evaluated in relation to the ${ }^{14} \mathrm{C}$ ages obtained for the same trench (see this paper 'Chronology of the analysed contexts: tie points for the definition of the human occupation of the Bergamo Hill in prehistoric-protohistoric times').

We accessed the stratigraphies below the Cathedral and the Palazzo del Podestà (Fig. 1c) and sampled/cored what was archaeologically defined as "sterile layers" due to the lack of artefacts, structures or deposits of anthropic signature. Those layers were preliminarily dated and analysed, providing evidence of early anthropic pressure on the
Bergamo hilltop since the 12th-11th century вС (Chiesa and Pini 2008; Pini et al. 2016). This paper analyses in detail the micro- and macrobotanical record preserved under the modern city and further extends back in time those previous data.

\section{The Bergamo Forealps-geoecological aspects and land use tradition}

The Bergamo Hills (360-550 m a.s.l.) belong to the external mountain ridges of the Italian Alps fronting the Po Plain, i.e. the Bergamo Forealps (Fig. 1b). These mountains are formed by limestone, clayey and cherty limestone, chert, and sandstone. The soil properties, pedoclimate and geoecology of vegetation growing on sandstone parent material, prevailing on the northern side of the Bergamo Hills (Fig. 1d, area "A", see "Coprophilous spores as a proxy for husbandry in Bronze Age Bergamo'), are different from those areas with prevailing limestone, where carbonate is easily leached. Quartz and feldspar are released while clay minerals are formed, resulting in thick colluvial wedges and paludal alluvial fills. These naturally weathered materials and soils are carbonate-free, and bear a high water capacity and low saturation of the exchange complex (Fig. 1e; Bonalumi et al. 1992; WRB, Iuss Working Group 2015). However, anthropogenic soil erosion on top of the Bergamo hills caused substantial bedrock denudation on the southern hill side (Fig. 1e), recharge of the saturation complex and, in some cases, also of active carbonate, especially on the steeper parts of the southern side (Fig. 1e, areas "N" and "B"). The resulting mosaic of variable reaction and water capacity conditions correlates to an extremely high biodiversity in low mountain grasslands of the Bergamo Forealps (see 'Indicator species of land use with special reference to zoochorous dispersal'). Traditional land use in these mountains, active until the Second World War, included livestock husbandry (see 'The mobility of pastoralists, ecological resources and gradients, and the development of Bronze Age settlements on the fringe of the Italian Alps'). Mean precipitation of $1,250 \mathrm{~mm} /$ year and significant orographic summer rainfalls characterize the humid climate in the westernmost Forealps, and exclude a summer drought typical for the Mediterranean climate (Crespi et al. 2018). However, eumediterranean plants (i.e. with a range centred in the mediterranean region but extending north- and eastward within the limit of the cultivated grape; Pignatti 2017-2018) occur both in the contemporary low-mountain vegetation of the Bergamo Forealps (Fig. 1b), and in the historical plant record (Wick and Mohl 1996; Gobet et al. 2000; Verde et al. 2010; Martinelli et al. 2017). Warm and dry habitats, suitable for thermophilous rocky, grassland and forest vegetation, are mostly edaphically-driven on south-facing slopes (Figs. 1b-e). Pristine and managed broad-leaved deciduous forests covering the lower mountain zones of the Prealps in late prehistory (dominated by Fagus, Abies, Quercus, Tilia, Alnus, Corylus) were converted 
into grassland, especially during the Middle Ages, a process terminated only in the 1970s, with the abandonment of traditional practices and fire suppression. Those practices limited forest to chestnut crop stands, open pastured and coppiced woodlands and a few remnants of old-grown forest (Zonca 1998). Clearing by fire promoted the development of Betula pendula groves and heaths in open woodlands, especially on acidic soils (Atkinson 1992; Andreis and Cerabolini 1995). Secondary grasslands were periodically managed by fire, by seasonal assignment of areas devoted either to transhumant ovicaprine herds or to large ruminant grazing, and two types of haymaking. Manured haymaking meadows at low altitude are characterized by Arrhenatherum elatius (see Oberdorfer 1964, 1977; Poldini and Oriolo 1994), their flowering sequence being distributed over several phenological phases (1. Taraxacum officinale; 2. Ranunculus acris; 3. grasses; 4. Apiaceae; 5. Centaurea nigrescens), with hay and honey type production. Among the several types of non-manured hay meadows, the Molinia arundinacea tall herb meadow deserves mentioning, because it is predicted by our study for Bronze Age Bergamo (see 'Indicator species of land use with special reference to zoochorous dispersal'). All the Molinia-rich meadow types share their mesic pedoclimate, but actually they span different ecological conditions from acidic to strongly alkaline.

The present research will contribute to shedding light on the origin of these types of herb vegetation and their palaeoecology in Bergamo, before the Celtic settlement started expanding the urban area over the farmland.

\section{Materials and methods}

\section{Cores and archaeological sections considered}

Materials for this research derive from two long sediment cores drilled by the SO.GE.TEC Company in 2005 and 2010 inside the Cathedral of Bergamo and the nearby Palazzo del Podestà (sites 1 and 2 in Fig. 1c). Drilling machines used in open-air sites could not operate in these historical buildings due to very limited accessibility, thus the use of smaller coring equipment was necessary. Beside cores, sediments also came from archaeological excavations in a medieval domus within Palazzo del Podestà (hereafter Domus dei Bragagnoli trench $\mathrm{C}$ ) and in the basement of the Cathedral of Bergamo (hereafter Cathedral trench C) (sites 3 and 4 in Fig. 1c). For a thorough description of cores and sections, readers are referred to Ravazzi et al. (2020). Table 1 lists the analyses performed on each of the stratigraphic contexts considered for this research.

\section{Radiocarbon dating}

16 samples were submitted to the 14CHRONO Centre of the Queen's University of Belfast for radiocarbon dating. Plant remains were isolated from sediments through wet sieving, carefully brush-cleaned under a stereomicroscope, taxonomically identified, and then oven-dried at $60-70{ }^{\circ} \mathrm{C}$ for a few hours. Table 2 reports the list of ${ }^{14} \mathrm{C}$ ages available and their calibration intervals (Fig. 2), obtained with Calib 7.0.4 based on the Intcal13 curve (Reimer et al. 2013). To avoid confusion, throughout the paper we do not refer to calibration probability intervals, but instead use the median probability of calibrated ages.

\section{Palaeoecology: methods, analysis and statistical data treatment}

\section{Microbotany}

90 sediment samples were submitted to standard laboratory treatments for palynomorph extraction, including HF and acetolysis. Samples were analysed at $\times 400, \times 630$ and $\times 1,000$ to identify pollen, fern and fungal spores, algal remains and other microbiological particles. Pollen identification is based on Punt and Hoen (2009), Reille (1992-1998), Moore et al. (1991), Beug (2004) and the CNR-IGAG reference collection. Nomenclature follows Beug (2004). Pollen-slide charcoal particles were counted distinguishing two size classes $(10-50 \mu \mathrm{m}$ and $50-250 \mu \mathrm{m}$ length). Lycopodium tablets were added for pollen and charcoal concentration estimation (Stockmarr 1971). At least 500 grains of upland plant pollen were identified in $74 \%$ of the

Table 1 List of analyses available for each stratigraphic context/site

\begin{tabular}{lllll}
\hline & Palazzo del Podestà core & Domus dei Bragagnoli trench C & Cathedral main core & Cathedral trench C \\
\hline Sedimentation type & Natural sedimentation & Natural to on-site deposits & Near/on-site deposits & On-site deposits \\
${ }^{14}$ C dating & 1 date & 5 dates & 6 dates & 4 dates \\
Magnetic susceptibility & Measured & Not measured & Measured & Measured \\
Microbotany & 2 samples & 30 samples & 58 samples & No \\
Anthracology & No & 12 samples & No & No \\
Plant macro-remains & No & 4 samples & No & 74 samples \\
Nutrients (P forms, C, N) & No & No & & No \\
\hline
\end{tabular}


Table $2{ }^{14} \mathrm{C}$ ages available for the analysed contexts. Only the $2 \sigma$ calibration interval with higher probabilities are shown. For a full list of calibration intervals (both $\mathrm{BP}$ and $\mathrm{BC} / \mathrm{AD}$ ), the reader is referred to Ravazzi et al. (2020)

\begin{tabular}{|c|c|c|c|c|c|c|}
\hline Lab code & Dated material & $\begin{array}{l}\text { Sample } \\
\text { weight }(g)\end{array}$ & $\begin{array}{l}\text { Sample, provenance } \\
\text { (site, depth, SU) }\end{array}$ & $\begin{array}{l}{ }^{14} \mathrm{C} \text { age } \\
\text { (yrs BP) }\end{array}$ & $\begin{array}{l}\text { Cal ages, } 2 \sigma \text {-range } \\
\text { (higher probability) }\end{array}$ & $\begin{array}{l}\text { Median probabilites } \\
\text { (cal BP, } \mathrm{BC} / \mathrm{AD} \text { ) }\end{array}$ \\
\hline Ub 40936 & 0.5 Quercus acorn & 0.1445 & $\begin{array}{l}\text { Cathedral trench C, } \\
\text { SU } 1000\end{array}$ & $2,470 \pm 27$ & $\begin{array}{l}2,427-2,716 \text { ВР }(98.4 \%) \\
767-478 \text { ВС }(98.4 \%)\end{array}$ & $2,583 \mathrm{BP}, 633 \mathrm{BC}$ \\
\hline $\mathrm{Ub} 40938$ & $\begin{array}{l}\text { Panicum/Setaria } 12 \\
\text { grains, Triticum } 1 \text { spi- } \\
\text { kelet fork, } 4 \text { glume } \\
\text { bases, } 1 \text { grain }\end{array}$ & 0.0111 & $\begin{array}{l}\text { Cathedral trench C, } \\
\text { SU } 431 \text { top }\end{array}$ & $2,580 \pm 24$ & $\begin{array}{l}2,710-2,757 \text { ВР }(99.9 \%) \\
808-761 \text { ВС }(99.9 \%)\end{array}$ & 2,739 вР, 789 вС \\
\hline Ub 40937 & Vicia cf. faba seed & 0.021 & $\begin{array}{l}\text { Cathedral trench C, } \\
\text { SU } 1022\end{array}$ & $2,674 \pm 27$ & $\begin{array}{l}2,749-2,809 \text { ВР }(84.4 \%) \\
860-800 \text { ВС }(84.4 \%)\end{array}$ & $2,775 \mathrm{BP}, 825 \mathrm{BC}$ \\
\hline Ub 40939 & $\begin{array}{l}\text { Carpinus charcoal frag- } \\
\text { ment }\end{array}$ & 0.3188 & $\begin{array}{l}\text { Cathedral trench C, } \\
\text { SU } 1022\end{array}$ & $2,705 \pm 25$ & $\begin{array}{l}2,759-2,851 \text { ВР }(100 \%) \\
902-810 \text { ВС }(100 \%)\end{array}$ & $2,802 \mathrm{BP}, 852 \mathrm{BC}$ \\
\hline Ub 40943 & Charcoal fragments & 0.0278 & $\begin{array}{l}\text { Cathedral main core, } \\
854-856 \mathrm{~cm}\end{array}$ & $2,615 \pm 42$ & $\begin{array}{l}2,701-2,845 \text { ВР }(96.4 \%) \\
896-752 \text { вС }(96.4 \%)\end{array}$ & $2,750 \mathrm{BP}, 800 \mathrm{BC}$ \\
\hline UBA 9262 & Wood fragment & & $\begin{array}{l}\text { Cathedral main core, } \\
932 \mathrm{~cm}\end{array}$ & $2,805 \pm 27$ & $\begin{array}{l}2,845-2,979 \text { ВР }(99.6 \%) \\
1030-896 \text { ВС }(99.6 \%)\end{array}$ & 2,907 BP, $957 \mathrm{BC}$ \\
\hline $\mathrm{Ub} 40941$ & Charcoal fragments & 0.0118 & $\begin{array}{l}\text { Cathedral main core, } \\
994-996 \mathrm{~cm}\end{array}$ & $2,829 \pm 29$ & $\begin{array}{l}2,854-3,006 \text { вР }(99.1 \%) \\
1057-905 \text { вС }(99.1 \%)\end{array}$ & $2,931 \mathrm{BP}, 981 \mathrm{BC}$ \\
\hline $\mathrm{Ub} 42140$ & Charcoal fragments & 0.0059 & $\begin{array}{l}\text { Cathedral main core, } \\
1,012-1,014 \mathrm{~cm}\end{array}$ & $2,889 \pm 30$ & $\begin{array}{l}2,927-3,081 \text { вР }(90.7 \%) \\
1132-978 \text { ВС }(90.7 \%)\end{array}$ & $3,020 \mathrm{BP}, 1070 \mathrm{BC}$ \\
\hline $\mathrm{Ub} 42141$ & Charcoal fragments & 0.0098 & $\begin{array}{l}\text { Cathedral main core, } \\
1,016-1,018 \mathrm{~cm}\end{array}$ & $2,850 \pm 30$ & $\begin{array}{l}2,876-3,059 \text { ВР }(100 \%) \\
1110-927 \mathrm{BC}(100 \%)\end{array}$ & 2,961 вP, $1011 \mathrm{BC}$ \\
\hline Ub 42142 & Charcoal fragments & 0.0056 & $\begin{array}{l}\text { Cathedral main core, } \\
1,020-1,022 \mathrm{~cm}\end{array}$ & $2,877 \pm 29$ & $\begin{array}{l}2,921-3,077 \text { ВР }(94.5 \%) \\
1128-972 \text { вС }(94.5 \%)\end{array}$ & $3,001 \mathrm{BP}, 1051 \mathrm{BC}$ \\
\hline UBA 19900 & Charcoal fragments & 0.072 & $\begin{array}{l}\text { Domus dei Bragag- } \\
\text { noli, trench C, room } \\
\text { 14, sect. S, SU } 240\end{array}$ & $1,952 \pm 30$ & $\begin{array}{l}1,858-1,951 \text { BP }(85.9 \%) \\
2 \text { BC-92 AD }(85.9 \%)\end{array}$ & $1,903 \mathrm{BP}, \mathrm{AD} 48$ \\
\hline UBA 19901 & Charcoal fragments & 0.1 & $\begin{array}{l}\text { Domus dei Bragag- } \\
\text { noli, trench C, room } \\
\text { 14, sect. S, SU } 435\end{array}$ & $2,942 \pm 34$ & $\begin{array}{l}2,985-3,183 \text { ВР }(97.7 \%) \\
1234-1036 \text { вС }(97.7 \%)\end{array}$ & 3,099 вР, 1149 вС \\
\hline UBA 19902 & Charcoal fragments & 0.122 & $\begin{array}{l}\text { Domus dei Bragag- } \\
\text { noli, trench C, room } \\
\text { 14, sect. S, SU } 349\end{array}$ & $2,885 \pm 47$ & $\begin{array}{l}2,917-3,159 \text { ВР }(93.9 \%) \\
1210-968 \text { вС }(93.9 \%)\end{array}$ & $3,017 \mathrm{BP}, 1067 \mathrm{BC}$ \\
\hline UBA 19903 & Charcoal fragments & 0.03 & $\begin{array}{l}\text { Domus dei Bragag- } \\
\text { noli, trench C, room } \\
14, \mathrm{~s} \text { ect. E, SU } 349 \\
(117 \mathrm{~cm})\end{array}$ & $2,908 \pm 29$ & $\begin{array}{l}2960-3083 \text { ВР }(77.1 \%) \\
1134-1011 \text { вС }(77.1 \%)\end{array}$ & 3,044 вP, 1094 вс \\
\hline UBA 19904 & Charcoal fragments & 0.032 & $\begin{array}{l}\text { Domus dei Bragag- } \\
\text { noli, trench C, room } \\
\text { 14, sect. E, SU } 434 \\
(185-188 \mathrm{~cm})\end{array}$ & $3,032 \pm 29$ & $\begin{array}{l}3157-3279 \text { ВР }(70.8 \%) \\
1330-1011 \text { ВС }(70.8 \%)\end{array}$ & $3,233 \mathrm{BP}, 1283 \mathrm{BC}$ \\
\hline Ub 40940 & Charcoal fragments & 0.0085 & $\begin{array}{l}\text { Palazzo del Podestà, } \\
\text { core } S 2,671 \mathrm{~cm}\end{array}$ & $3,138 \pm 31$ & $\begin{array}{l}3324-3414 \text { ВР }(73.4 \%) \\
1465-1375 \text { ВС }(73.5 \%)\end{array}$ & $3,365 \mathrm{BP}, 1415 \mathrm{BC}$ \\
\hline
\end{tabular}

analysed samples (min 505, max 804, total grains identified 43,394). Pollen percentages reported in Figs. 3, 4, 6 refer to the sum of trees, shrubs and upland herbs. Aquatic and wetland species, spores, algae and other microbiological particles are excluded from this sum. Tilia 2.1.1 (Grimm 2004) was used for \% calculations and preparation of stratigraphical diagrams from Domus dei Bragagnoli trench $\mathrm{C}$ and the Cathedral main core (Figs. 4-6), then exported into CorelDraw for further elaboration.

Zonation of the pollen records from the Cathedral main core and Domus dei Bragagnoli trench $\mathrm{C}$ was obtained through constrained incremental sums of squares cluster 
Fig. 2 Chronological distribution of ${ }^{14} \mathrm{C}$ ages from cores and trenches analysed from the Bergamo hilltop. Subdivision in cultural phases is valid for Northern Italy and it is based on De Marinis (1999 and 2014)

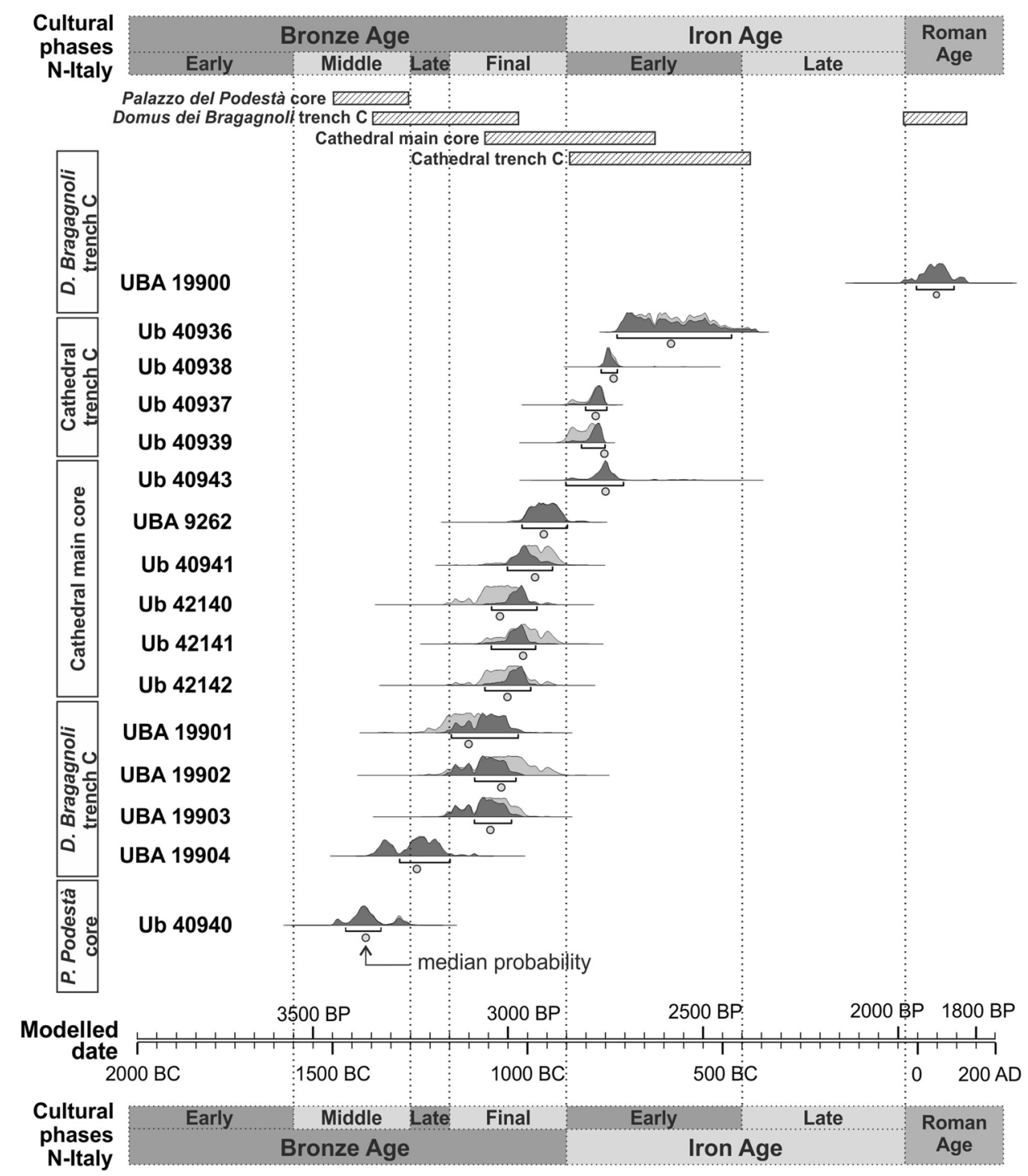

analysis performed with CONISS (Grimm 1987). Edwards and Cavalli-Sforza's chord distance was used as dissimilarity coefficient. The analysis runs on a selection of taxa displaying values $>2 \%$ in the interval under consideration. Individual rarefaction and alfa-diversity indexes (Dominance, Shannon) are calculated for the same records with the software PAST_PAleontological STatistics vers. 3.25 (Hammer et al. 2001) (Figs. 4-6).

Ordination techniques were applied on the Cathedral main core data to detect major compositional changes and relationships with environmental parameters. PCA (Principal Component Analysis) was performed on the covariance matrix of log-transformed \% data. Data standardization and ordination were carried out with the Vegan and Decorana packages (Oksanen et al. 2019) in R environment ( $R$ Core Team 2020, version 3.6.1). A graph displaying sites and species is presented in Fig. 8. Rare pollen types identified are shown in Fig. 7.

\section{Botanical macroremains}

Botanical macrofossils were studied from a total of 14 samples covering the time window considered in this study. Wood charcoal and seeds/fruit remains were extracted from sediment samples collected from archaeological trenches dug underneath Domus dei Bragagnoli (trench C; nine samples) and the Cathedral (trench $C$; five samples). The average volume of samples was respectively 2.291 and 1.351 . The sampling of larger volumes of sediment was hampered by safety and logistic limits, imposed by the location of the trenches and unstable sections within them. Samples were processed using a wash-over technique (Hosch and Zibulski 2003), employing 4, 2, 1, and $0.35 \mathrm{~mm}$ sieves.

Wood charcoal analysis was conducted on nine of the aforementioned samples, all coming from Domus dei Bragagnoli trench C. In view of the low density of macroscopic charcoal, the study was conducted on the entire fraction 


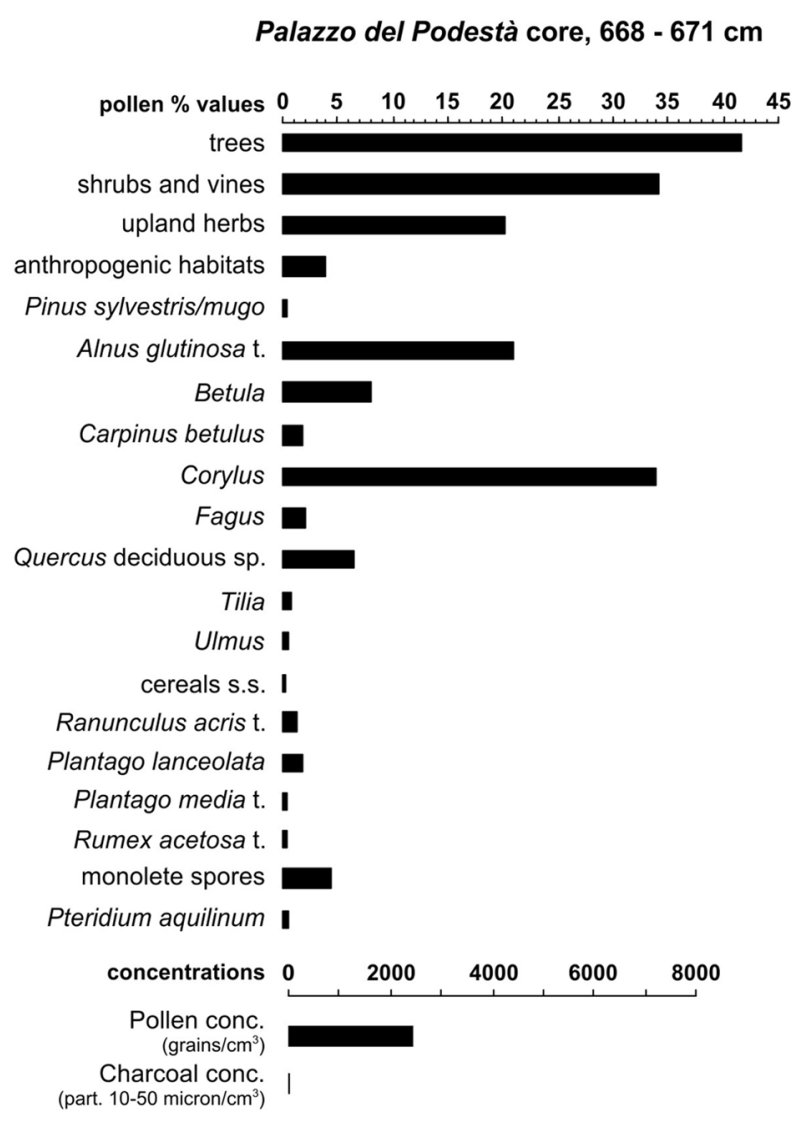

Fig. 3 Percentage values of selected pollen types in the lowermost sample analysed from the Palazzo del Podestà core

larger than $2 \mathrm{~mm}$. Specimens were examined in the three main sections with an episcopic microscope (Zeiss Axio Scope A.1 equipped with a dark field/bright field illumination system). Wood atlases (e.g. Jacquiot et al. 1973; Schweingruber 1990) and the CNR-IGAG modern reference collection were used for the botanical identification.

Carpological analysis was carried out on the five samples from the Cathedral trench $\mathrm{C}$ and on four samples from Domus dei Bragagnoli trench C (five samples yielded no remains). Seeds and fruits were sorted and identified using a Leica/Wild M3C stereoscopic binocular microscope with a 6.4 to $40 \times$ magnification. Identifications were carried out with the support of the modern seed reference collection of CNR IGAG and the aid of seed atlases and identification manuals (Berggren 1981; Cappers et al. 2006; Jacomet 2006; Neef et al. 2012). The botanical nomenclature follows Pignatti 2017-2018) for wild plants and Zohary et al. (2012) for cultivated plants.

Concentrations of plant remains (wood charcoal, seeds and fruits) per litre for each sample were calculated using the volumes of the samples measured in water. Results are presented in Fig. 5.
Developing quantitative ecological proxies based on microand macrobotanical remains

Plants identified by their micro- and macrobotanical evidence are used to trace changes in communities on the Bergamo Hill during eight centuries, from the 15th to the 7 th century BC. We interpreted the original palaeoecological data presented in Figs. 3-6: pollen types and other microbiological proxies diagnostic for specific ecological groups are summed and used as proxies for forests, herb communities and farming practices. Based on the palynomorph types identified, and taking into account the vegetation ecology of the area, i.e. in the low mountain belt of the southern side of the Alps (see 'The Bergamo Forealps-geoecological aspects and land use tradition'), we compiled a synoptic table (Table 3 ) matching microbotanical types with macrobotanical taxa, and with the synecological and phytosociological framework available for the Northern Italian vegetation (based on Oberdorfer 1964, 1977, 1983; Sutter 1962; Meyer 1977; Ellenberg 1988; Ravazzi 1992; Feoli Chiapella and Poldini 1993; Verde et al. 2010). The botanical nomenclature follows Pignatti (2017-2018); Zohary et al. (2012) is adopted for cultivated plants. This procedure is adapted on (a) the overall fossil palaeoflora (94 pollen types, 43 fruit and seed types, 7 charcoal types); (b) the modern regional ecological context. As our study refers to a hilltop context, the aquatic vegetation is limited to a few riparian communities. Interestingly, we found a high biodiversity of herb taxa, predicting several grassland habitats, from carbonate-rich dry fallow to pastures with variable pedoclimate and soil alkalinity. The variability of the grassland ecology is not fully considered in the groups distinguished in Table 3. This will be discussed based on indicator taxa in the palaeoflora (see 'Indicator species of land use with special reference to zoochorous dispersal').

Beside ecological/ethnographical groups, pollen spectra from the Cathedral main core allowed the distinction of a taphonomical group (Table 3) with pines and Cichorioideae abundance used as diagnostic pollen types for selective degradation and for long-distance transport. In 'The Cathedral main core: a high-resolution microbotanical and pedochemical archive from the 12th to the 8th century вС' we show how this group helps in the interpretation of biased pollen zones identified in the Cathedral main core record.

\section{Magnetic susceptibility}

Volume magnetic susceptibility ( $\left.\kappa 10^{-5} \mathrm{SI}\right)$ was measured on the Cathedral and Palazzo del Podestà cores, and on the Cathedral trench C context. We used a Bartington MS2 susceptometer equipped with a MS2E sensor operating on a $2 \mathrm{kHz}$ 
Domus dei Bragagnoli, trench C

biodiversity indexes and selected paleoecological proxies
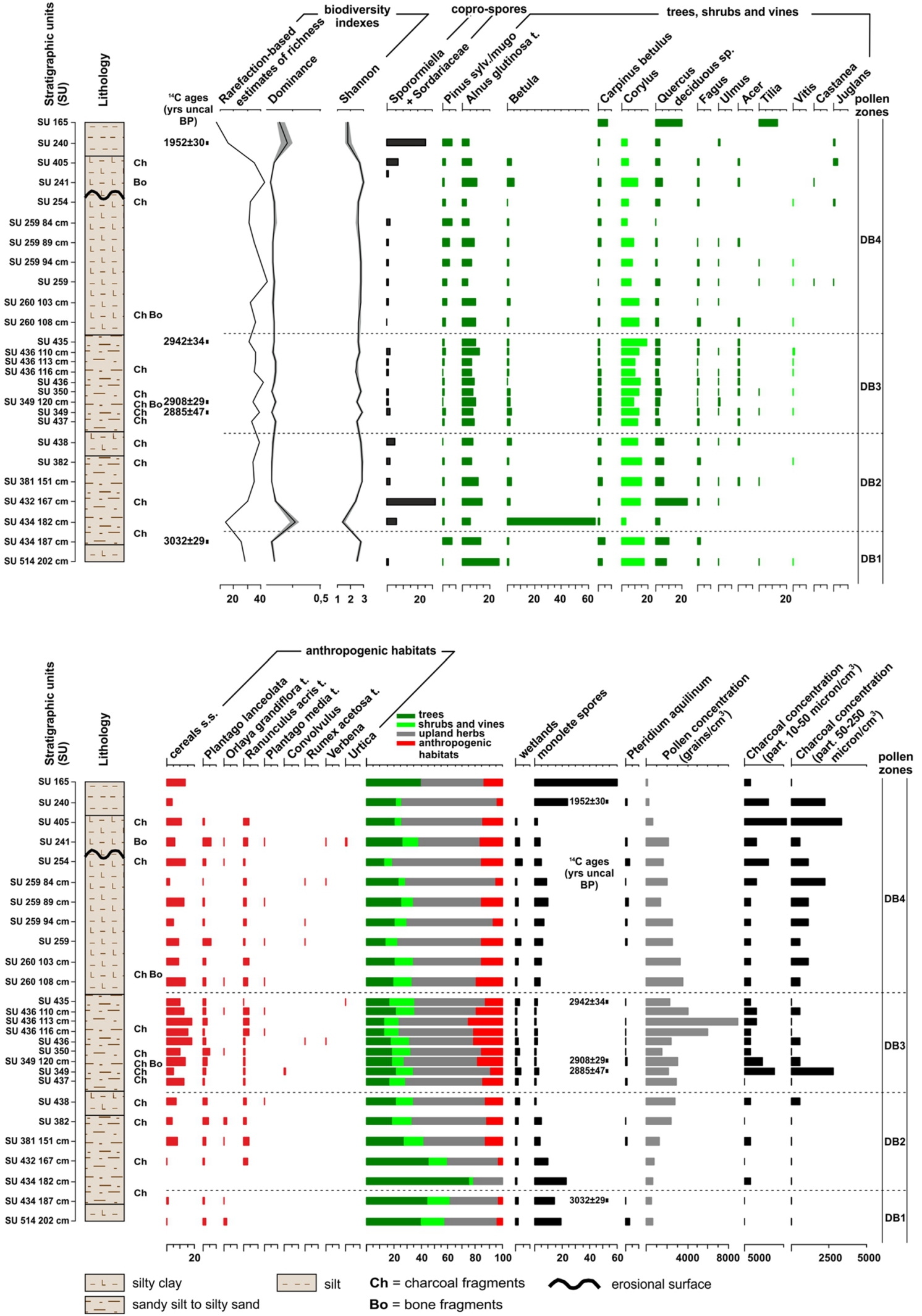

Fig. 4 Palaeoecological record (selected taxa) from Domus dei Bragagnoli trench C 


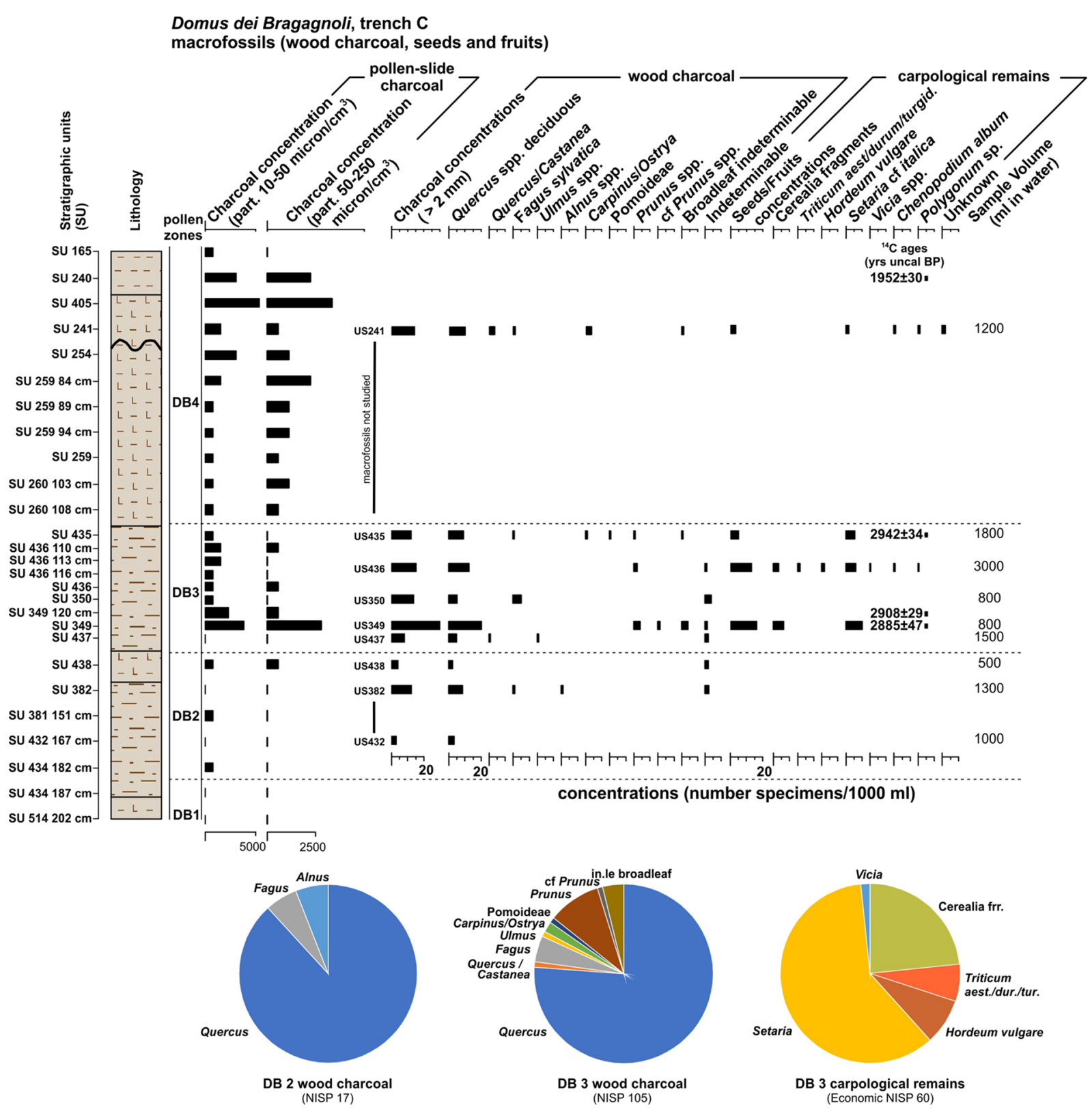

Fig. 5 Domus dei Bragagnoli, trench C, result of the macrobotanical study. For lithology, pollen zones, and microcharcoal concentration see also Fig. 4. In the plot, anthracological and carpological data are

frequency. The volume susceptibility record for the Cathedral main core is shown in Fig. 6. An environmental threshold at $\kappa=5010^{-5}$ SI separates environmental materials from burnt soils and baked clay-rich sediments (Ravazzi et al. 2020).

\section{Pedochemistry}

Concentrations of phosphorus forms (total, organic, inorganic and available) were determined following soil chemistry procedures (Colombo Miano, 2015) on sediments represented as concentrations (number of remains $/ 1,000 \mathrm{ml}$ ). The pie charts represent relative abundances calculated excluding indeterminate specimens and grouped according to palynological zones

from the Cathedral main core. Total $\mathrm{P}$ was extracted by hot aqua regia treatment in a microwave oven after organic matter removal with hydrogen peroxide. Organic P was calculated as the difference between $\mathrm{P}$ obtained after sulfuric acid treatment with and without heating at $550{ }^{\circ} \mathrm{C}$; inorganic $\mathrm{P}$ was obtained as the difference between total and organic P. Available P was extracted with sodium bicarbonate (Olsen method). After extraction, $\mathrm{P}$ forms were determined spectrophotometrically via blue phosphomolybdate complex. 

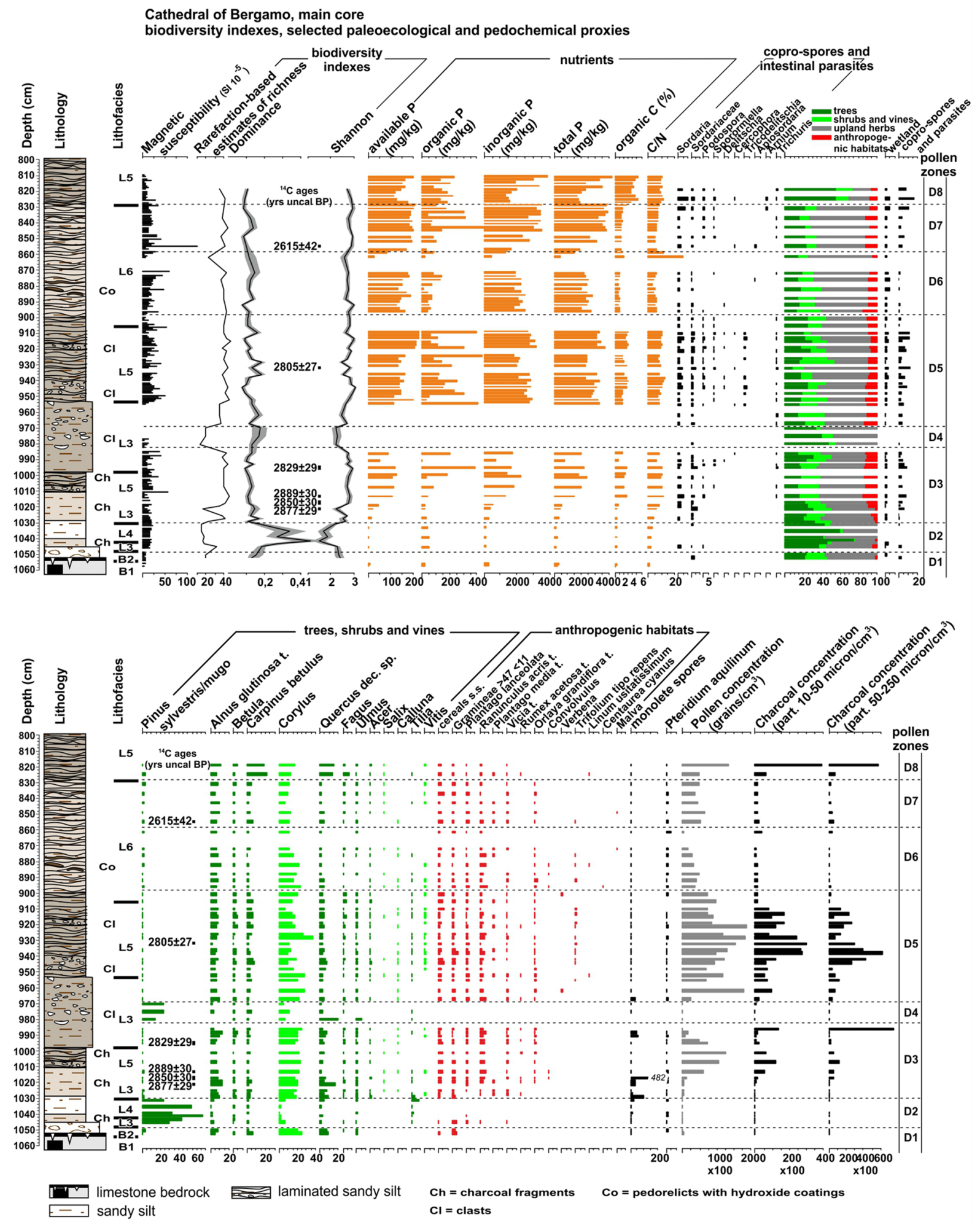

Fig. 6 Palaeoecological record (selected taxa) and pedochemical data from the Cathedral main core

Samples for $\mathrm{C} / \mathrm{N}$ determination were analysed by dry combustion after carbonate removal by $\mathrm{HCl}$, to determine soil organic carbon and total nitrogen content (Flash EA
1112 NCSoil, Thermo Fisher Scientific elemental analyser, Pittsburgh, PA, USA). Total $\mathrm{K}$ was extracted in aqua regia in microwave oven and determined through AAS (atomic 


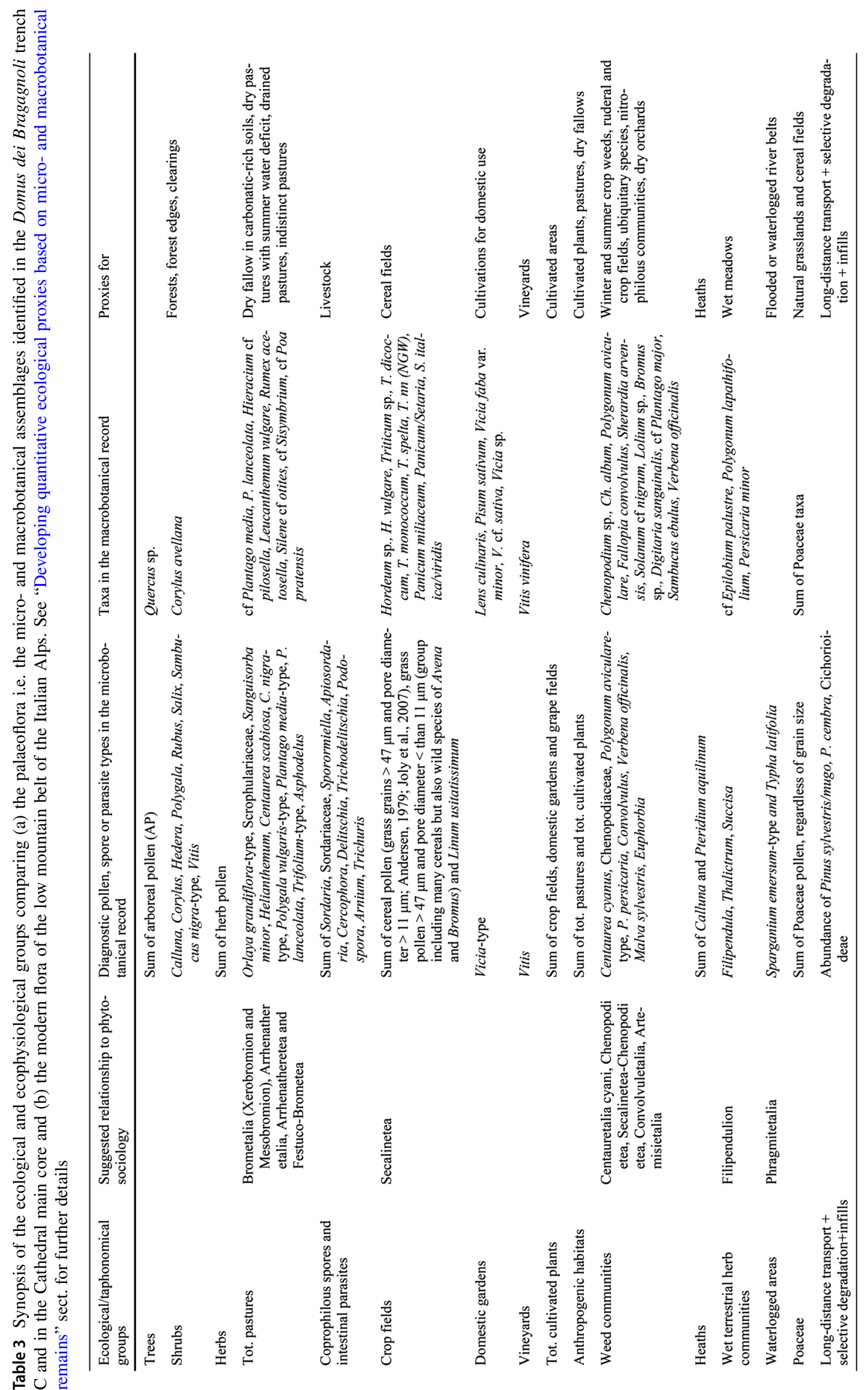


absorption spectroscopy). Results are shown in Fig. 6 along with palaeoecological data.

\section{Results and data interpretation}

We present multiproxy data together with their interpretation in terms of local and regional vegetation structure, as well as proxies indicating human activities (plant husbandry, livestock management). A chronological approach will be adopted following the framework provided in Fig. 2; the narrative will start with the oldest evidence (Middle Bronze Age) and then progress regularly through time till the Early Iron Age.

\section{Chronology of the analysed contexts: tie points for the definition of the human occupation of the Bergamo Hill in prehistoric-protohistoric times}

The available radiocarbon chronology from the four contexts (see Table 2) provides a framework to locate in time and space the human presence in the heart of the Old Town of Bergamo (Fig. 2).

The $2 \sigma$ calibration interval of the Ub 40940 date $(3,138 \pm 31$ uncal yrs $\mathrm{BP}$, from a charcoal fragment at $671 \mathrm{~cm}$ depth in the Palazzo del Podestà core), yielded a higher probability between 3,324-3,414 cal yrs вр / 1465-1375 cal yrs BC, with a median value of 3,365 cal yrs BP / 1415 cal yrs BC. This age is the oldest so far available for the development of farming activities on the Bergamo Hill in the Middle Bronze Age.

The sequence from Domus dei Bragagnoli trench C covers a time span of several centuries, from the 13 th century $\mathrm{BC}$ (Late Bronze Age, UBA 19904) to the 12th-11th century BC (Final Bronze Age, UBA 19903, 19902, 19901) and then to the 5th century AD (Roman times, UBA 19900). This stratigraphic record developed mostly in an anthropized depositional context, thus its continuity is biased by cuts and other earthworks. Nevertheless, its palaeoecological data provide evidence of increasing human pressure on the natural environments since its onset (see 'Micro- and macrobotany of the Domus dei Bragagnoli trench $\mathrm{C}$ from the 13th century BC' and Fig. 4).

A set of ${ }^{14} \mathrm{C}$ ages centred in the 11 th-10th century $\mathrm{BC}$ (Final Bronze Age) comes from the Cathedral main core. From dates Ub 42142 to UBA 9262, radiocarbon determinations coupled with palaeoecological data (see 'The Cathedral main core: a high-resolution microbotanical and pedochemical archive from the 12 th to the 8 th century BC' provide a consistent pattern of human settlements and activity on the Bergamo Hill. Date Ub 40943 has a median probability centred in the 9th century BC (Early Iron Age).
${ }^{14} \mathrm{C}$ determinations so far available offer a chronological junction between the Cathedral main core record (Fig. 6) and the carpological determinations from the nearby Cathedral trench C (Fig. 11), supported by a set of four radiocarbon ages (Ub 40936 to 40939) falling between the 9 th and 7 th century BC.

\section{The earliest evidence of farming activities at the end of the 15th century вс from the Palazzo del Podestà core}

Pollen data from 668-671 cm depth in the Palazzo del Podesta core (site 2 in Fig. 1b; Fig. 3) depict the image of past vegetation preserved in natural colluvial deposits. The level, ${ }^{14} \mathrm{C}$ dated by a charcoal fragment at $671 \mathrm{~cm}$ to $3,138 \pm 31$ uncal yrs BP, sets its deposition towards the end of the 15 th century BC. Although no macroscopic artefacts were detected in the sieved core sediment fractions, in agreement with low volume susceptibility values (Ravazzi et al. 2020), their microscopic biological content speaks for early human activities on the Bergamo Hill. Pollen of trees and shrubs sums up to $76 \%$, with an abundance of hygro-mesophilous broadleaved forest taxa such as Corylus, Alnus glutinosa-type, Betula, deciduous species of the genus Quercus, Fagus and Carpinus betulus. Pollen grains of cereals, Ranunculus acris-type, Plantago lanceolata and $P$. media, Rumex acetosa-type suggest farming activities. We must be careful in proposing a reconstruction of past landscapes based on one single pollen spectrum, as far as the extent and nature of human impact is concerned. Nevertheless, we interpret the available data as evidence of limited although ongoing human impact on the vegetation of the Bergamo Hill by the 15 th century BC (Middle Bronze Age) farmers. Such activity was possibly of reduced extent and did not include the use of fire to open the landscape, as shown by low charcoal concentration in sediments.

Pollen data from 550-552 cm depth (see ESM 1) pertain to a pluricentimetric layer of micaceous sands with accumulations of small and flat microscopic charcoal fragments, yielding peaks of magnetic susceptibility over the environmental threshold (Ravazzi et al. 2020). Pollen of trees and shrubs sums up to ca. $50 \%$. Compared to the lowermost pollen spectrum, pollen percentages of Corylus, Alnus glutinosa-type and Betula decrease sharply, while Fagus and Carpinus betulus moderately increase. Farming is predicted by an abundance of cereal pollen, P. lanceolata, Ranunculus acris-type, Vicia-type, Orlaya grandiflora-type and single grains of Malva. No ${ }^{14} \mathrm{C}$ age is available for this layer; a comparison with the continuous palaeoecological record from the Cathedral main core suggests setting it during the 12 th-10th century вс (Final Bronze Age). 


\section{Micro- and macrobotany of the Domus dei Bragagnoli trench C from the 13th century $\mathrm{BC}$}

\section{General overview}

The Domus dei Bragagnoli trench C (site 3 in Fig. 1b) yielded a thick record of deposits in a near-site position to a settlement, covering the period from the 13th century BC to the 13th-15th century AD (Fortunati 2012; Poggiani Keller 2012; Pini et al. 2016). Units were studied for their micro- and macrobotanical content, with the support of 4 radiocarbon dates. The composite record is shown in Fig. 4; for the purposes of this paper, the uppermost interval of post-Roman age is not shown.

\section{Pollen deposition model}

Pollen spectra suggest a prevalent airborne deposition. Although individual coprolites were not found, transport by animal droppings is not excluded. A huge and isolated peak of Betula pollen in one sample (see 'Biodiversity estimates') suggests winter foddering with catkins, a well-documented practice known from Neolithic and Bronze Age pile-dwellings (Rasmussen 1990; Akeret et al. 1999).

\section{Vegetation history: micro- and macrobotanical evidence}

The palaeoecological record is subdivided in four pollen zones (DB1 to DB4). The study provided evidence of farming activities since the basal stratigraphic unit (SU 514), which was actually devoid of human artefacts. In this phase the Bergamo Hill hosted deciduous forests with Alnus glutinosa-type, Corylus, Quercus and Betula. We observe many similarities between the basal pollen zone DB1 and the 15th century вс (Middle Bronze Age) spectrum from Palazzo del Podestà core (see Fig. 3 and 'The earliest evidence of farming activities at the end of the 15th century вС from the Palazzo del Podestà core'), apart from a sharp decrease of shrub pollen (notably Corylus) coupled with increasing total herb pollen.

Pollen zones DB2 and DB3 document major landscape changes that took place on the Bergamo Hill between the 12th-11th century вс (Final Bronze Age) and the onset of the Early Iron Age. Hygro-mesophilous forests experienced a strong contraction, from 75 to $25 \%$ of the pollen sum, mostly affecting Alnus glutinosa-type and deciduous species of the genus Quercus. Sediments contain large amounts of oak charcoals, testifying that oak stands were exploited for firewood purposes (Fig. 5). The trench $\mathrm{C}$ sequence developed in a near-site position to a settlement (sensu Edwards 1991; Ravazzi et al. 2019) and its stratigraphic continuity is biased by anthropic cuts; available ${ }^{14} \mathrm{C}$ ages can be used with great caution to constrain in time the major AP drop record in zone DB2. Ages obtained for SU 349 (UBA 19902 and $19903,2,885 \pm 47$ and $2,908 \pm 29$ uncal yrs BP, respectively) are statistically the same at $95 \%$ level. Their mean pooled radiocarbon age corresponds to $2,901 \pm 25$ uncal yrs BP, with a median probability of 3,034 cal yrs BP / $1084 \mathrm{cal}$ yrs BC (11th century вс, Final Bronze Age). We can infer that the AP drop occurred sometime between 1283 (median prob. of date UBA 19904) and $1084 \mathrm{cal} \mathrm{yr} \mathrm{BC.} \mathrm{Areas} \mathrm{cleared} \mathrm{from}$ forests were used as crop fields, as indicated by the high pollen $\%$ of cereals (up to 15-17\%) and of their weeds (Orlaya grandiflora-type, Convolvulus). Carpological analysis in $\mathrm{SU}$ 349-436 (zone DB3) includes the following cereals, which, based on airborne pollen abundance, were most probably cultivated on the hilltop, i.e. naked wheats (Triticum aestivum/durum/turgidum), barley (Hordeum vulgare) and possible foxtail millet (Setaria $\mathrm{cf}$. italica). Beside pollen of indicators of meadows and pastures rich in nutrients (P. lanceolata, P. media-type, Ranunculus acris-type; Vicia-type, Polygonum aviculare-type), spores of coprophilous fungi are recorded, indicating the presence of livestock.

Macroscopic wood charcoal found in low concentrations (average 12 fragments $>2 \mathrm{~mm}$ for litre of sediment) in the deposits associated with pollen zones DB2 and DB3 likely originated from anthropic fire activities in proximity to the depositional environment (Fig. 5). Because of the low count number (number of identified specimens (NISP) $=17$ fragments), a cautious approach is needed in quantitatively evaluating wood charcoal data from the units attributed to the zone DB2. Nevertheless, a dominance of deciduous oaks (Quercus spp. deciduous) and the additional presence of beech (Fagus sylvatica) and alder (Alnus spp.) supports the image reconstructed through pollen analysis. Quantitatively more reliable are the anthracological data from the deposits associated with pollen zone DB3. Deciduous oaks retained a dominant role, associated however with a higher number of secondary taxa (Fig. 5). If the increase in floristic richness might be seen as a direct consequence of the increased number of specimens analysed (NISP 102), then on the other hand a relatively ubiquitous attestation of taxa associated with forest clearings, such as Rosaceae (Prunus spp. and Pomoideae s.l.) and hornbeams (Carpinus sp./Ostrya sp.), should be noted. This picture is consistent with a phase of contraction of the oak dominated deciduous forest and consequent expansion of glades. Both associations were exploited for firewood purposes, with however a possible preference toward the exploitation of oaks thus suggesting an increase of the firewood catchment area in response to the hilltop deforestation.

Pollen zone DB4 covers a time window of several centuries, from the Early Iron Age to the 1st century AD with 
a potential hiatus at the erosional surface between SU 254 and SU 241 (Figs. 4-5). Afforestation maintains values comparable with zone DB3, although some taxa (i.e. Corylus) decrease further. High percentages of cereal pollen document crop fields throughout the period; carpological analysis from SU 241 records charred grains of foxtail millet (Setaria cf. italica). Pollen spectra record indicators of manured and mowed meadows and pastures, such as Heracleum sphondylium-type, P. lanceolata, and Trifolium. Spores of Pteridium aquilinum appear in almost all samples, suggesting fire activity on acidic soils. Layers rich in microscopic charcoal fragments often intercalate with layers rich in stones and even animal bones (SU 241), as typical of ruderal areas including domestic lots or rubbish.

\section{Biodiversity estimates}

Rarefaction analysis (Fig. 4) suggests a substantially stable estimated palynological richness through zones DB2 to DB4, with a mean number of 34 identified pollen types. Lower values are estimated for SU 434 at the base of zone DB2 as the pollen sum is quickly saturated due to an enormous peak of Betula pollen and in the upper part of zone DB4 an abundance of Cichorioideae pollen, suggesting either pollen preservation issues or animal droppings. The rarefaction curve finds counterparts in the Dominance curve, which is substantially stable throughout the whole record with values closer to zero indicating that all taxa are equally present. Positive peaks (values closer to 1) correspond to SU 434 and to the upper part of zone DB4, indicating that those samples are dominated by a reduced number of taxa. Similar results are provided by the Shannon diversity index, which takes into account the number of individuals as well as the number of taxa. Communities with one/few taxa with high values are identified by lower values of the Shannon index (again, SU434 and topmost zone DB4) while communities with many taxa each with few individuals yield higher values for the index.

\section{The Cathedral main core: a high-resolution microbotanical and pedochemical archive from the 12th to the 8th century $B C$}

\section{General overview}

The $10.60 \mathrm{~m}$-long stratigraphic sequence preserved below the Cathedral of Bergamo (site 1 in Fig. 1b) is composed of ca. $6 \mathrm{~m}$ of fine-grained near-site deposits covered by metres of constructional deposits of Roman and Medieval age (Ravazzi et al. 2020). A robust chronological model (Fig. 2) sets the beginning of sediment deposition in the 12th century BC (Final Bronze Age). Pollen preservation is good throughout the analysed materials (Fig. 7), suggesting deposition in a water-saturated environment. Examination of the sedimentary structures visible on the longitudinally-sectioned core, its persistent lamination and its micro- and macroscopic content let us hypothesize that the sequence originated as infill of a watering pond used for animal husbandry (Ravazzi et al. 2020). The large amount of palaeoecological and pedochemical data obtained on the $810-1,060 \mathrm{~cm}$ section of the Cathedral main core (Fig. 6) describes at great resolution the history of plant landscapes, land use and human activities through a period of ca. four centuries, from the 12th to the 8th century вС (Final Bronze Age to the Early Iron Age).

\section{Pollen deposition model}

Spectra from the Cathedral main core suggest several mechanisms of pollen focussing: (i) atmospheric pollen transport (pollen release, wind transport, dispersal at different scales, deposition), (ii) intensive runoff at the base of the slope where sedimentation occurred in a watering pond (Ravazzi et al. 2020), (iii) pollen conveyed by animal droppings, and on their fur. The relevant source area of pollen conveyed by animals and runoff cannot be predicted by general models of airborne pollen circulation. Low dispersibility pollen discharged by animals, by humans (hay and cereal stubbles: Greig 1984) and/or transported by runoff processes before incorporation in sediments may be strongly overrepresented in the context of a watering pond with an accumulation of laminated mud (Kühn et al. 2013). This feature may explain the abundance of usually low-represented large pollen grains (Anthericum, occurring in 18 out of 58 samples), often echinate (Dipsacus in 29 samples, mean value $0.4 \%+$ and other Dipsacaceae, Centaurea nigra-type in 51 samples, mean value $3.8 \%$ ), as well as of very large rare pollen types (Asphodelus) and of other pollen types foraged on dry grasslands (Orlaya grandiflora-type, Helianthemum, see Perego et al. 2011; Rösch 2018) detected in these samples.

\section{Vegetation history}

The palaeoecological record is subdivided in eight pollen zones (D1 to D8). Zone D1 records AP values comparable to those observed in the DB2 to DB3 zones of the Domus dei Bragagnoli trench C (cfr 'Micro- and macrobotany of the Domus dei Bragagnoli trench C from the 13th century BC'), describing hygro-mesophilous forests. The presence of cereal pollen (grains larger than $47 \mu \mathrm{m}$ and pore diameter larger than $11 \mu \mathrm{m}$ : Andersen 1979; Joly et al. 2007), accompanied by grass pollen larger than $47 \mu \mathrm{m}$ and pore diameter smaller than $11 \mu \mathrm{m}$ (a group including many cereals but also wild species of Avena and Bromus), and Sordariaceae spores indicates farming activities area in the proximity of the drilling site. Organic $\mathrm{C}$ in sediment is below $1 \%$ and $\mathrm{C} / \mathrm{N}$ ratio below 5: such values are compatible with the rapid burial, 
Fig. 7 Photographs of selected pollen grains, spores, intestina parasites and plant macrofossils identified in the sediments of the Cathedral main core $\mathbf{a - i}$ and Cathedral trench $\mathrm{C} \mathbf{j}-\mathbf{m}$. Pictures of microfossils are taken at $1,000 \times$. a Asphodelus albus-type, sample $872 \mathrm{~cm}$; b Linum usitatissimum, sample $952 \mathrm{~cm}$; c Orlaya grandiflora, sample $952 \mathrm{~cm}$; d Polygonum aviculare-type, sample $952 \mathrm{~cm}$; e Vicia-type, $967 \mathrm{~cm}$; f Knautia arvensis-type, $995 \mathrm{~cm} ; \mathbf{g}$ ) Pteridium aquilinum, $962 \mathrm{~cm} ; \mathbf{h}$ Podospora, $613 \mathrm{~cm}$; i Trichuris, sample $613 \mathrm{~cm} ; \mathbf{j}$ Digitaria sanguinalis; $\mathbf{k}$ Verbena officinalis; $\mathbf{l}$ Leucanthemum vulgare; $\mathbf{m}$ Plantago lanceolata. Scale bar for macrofossils $=1 \mathrm{~mm}$
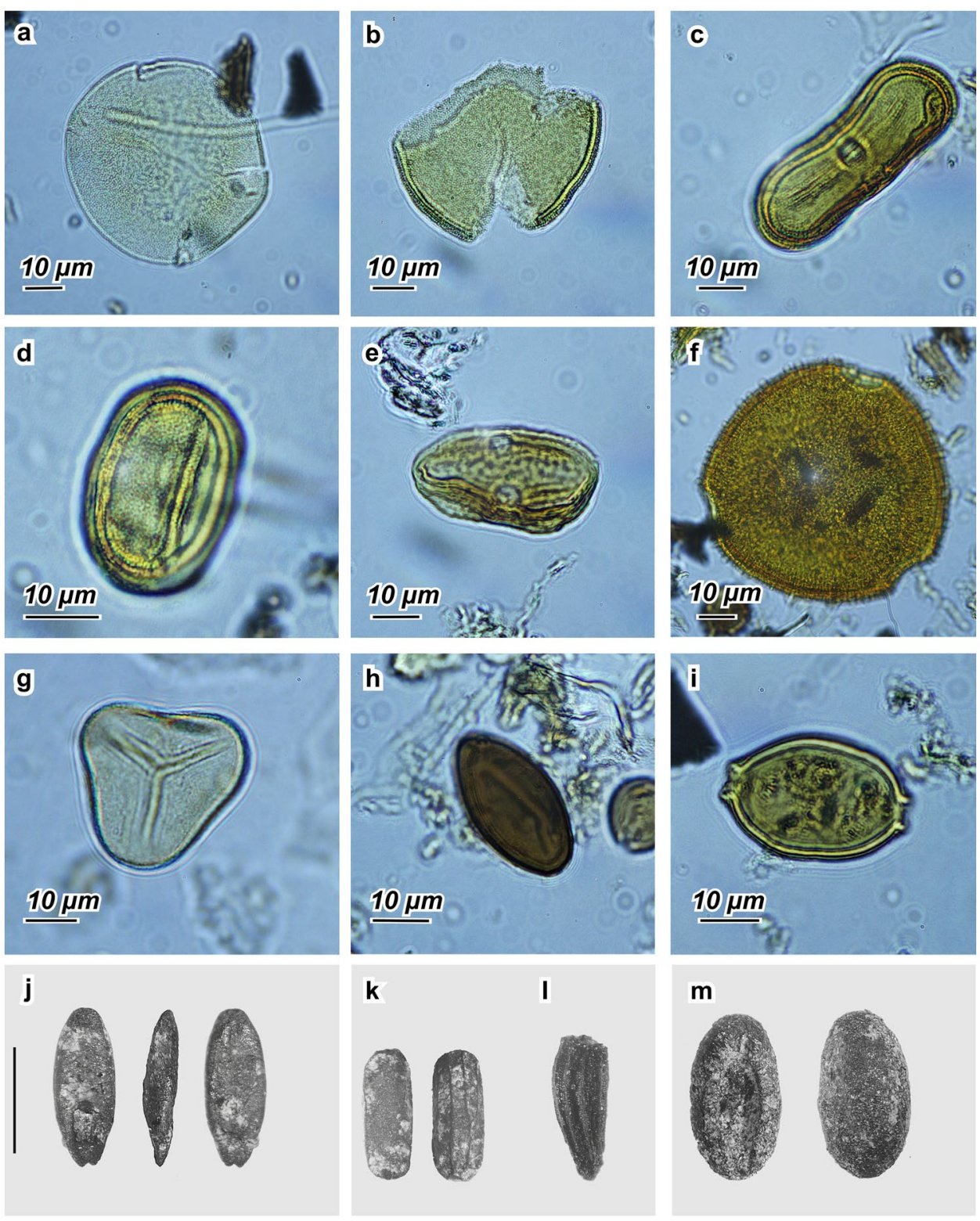

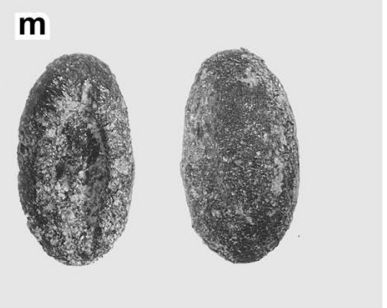

induced by high sedimentation rates, of fresh organic matter with a high nitrogen content (Rizzitano and Alquati 1997). Limited $\mathrm{P}$ forms concentrations in the sediments point to low nutrient availability.

Between the 11th-8th century вС (Final Bronze Age up to the beginning of the Iron Age-zones D3-D5 to D7) palaeoecological data from the Cathedral main core support the picture reconstructed on the basis of coeval evidence from the Domus dei Bragagnoli trench C. High charcoal concentrations, particularly in zones D3 and D5, suggest increased on-site fire activities from enhanced anthropic pressure. A wide spectrum of farming activities involving both plant and animal husbandry are indicated by microbotanical proxies, i.e. the presence of crop fields (based on the continuous record of cereals and a single but highly diagnostic pollen grain of Linum usitatissimum, see Viklund 2011 and 'Indicator species of land use with special reference to zoochorous dispersal'), domestic gardens or manured meadows and pastures (P. lanceolata and P. media-type, Orlaya grandifloratype, Rumex acetosa-type, Ranunculus acris-type). The presence of grapevine cultivation is supported by continuous pollen occurrences of Vitis with percentages $>1 \%$ and finds of pip fragments dated to 2,780 cal yrs BP / $830 \mathrm{cal} \mathrm{yrs} \mathrm{BC}$ (median probability) in the Cathedral trench $\mathrm{C}$ (see 'Fruits and seeds from the Cathedral trench C' and Ravazzi et al. 2020).

Ruderal and nitrophilous communities settled on disturbed areas are indicated by Convolvulus, Polygonum aviculare-type, Verbena, Euphorbia and Malva. Livestock husbandry (Table 3 ) is documented by the continuous and 
biodiversity-rich record of coprophilous spores (among them Sordaria-type, Sporormiella, Podospora, Delitschia, Tricodelitschia, Cercophora, Apiosordaria, Arnium) and intestinal parasites (Trichuris). This record, coupled with very high $\mathrm{P}$ concentrations in sediments, points to focussing of animal manure in water-saturated depressed areas by runoff and subsequent release of nutrients (Sharpley and Moyer 2000), and of pollen conveyed by animal droppings and runoff (see 'Pollen deposition model'). During zones D3 and $\mathrm{D} 5$ organic $\mathrm{C}$ is almost constantly above $3 \%$ and $\mathrm{C} / \mathrm{N}$ ratio is 10: this value is typical for agrarian soils and suggests enhanced microbial activity leading to an effective degradation of organic matter added to the soils (Osman 2013). Inorganic $\mathrm{P}$ concentrations are very high $(\geq 2,000 \mathrm{mg} / \mathrm{kg}$ of sediment); it is well known that after long periods of high $\mathrm{P}$ inputs through mineral and organic fertilizers, agricultural soils can also exhibit significantly higher P contents (up to more than 2,000 mg/kg) (Blume et al. 2016). Determinations of potassium concentrations on a limited number of samples (not shown in Fig. 6) reveal high amounts of this element, which might derive from wood or bone ashes, in turn responsible for the high inorganic $\mathrm{P}$ content and release of biogenic silica (Etiégni and Campbell 1991; Schiegl et al. 1994; Figueiredo et al. 2010). Ash and microcharcoal concentration in this context may result from local charcoal production or by upland runoff affecting burnt woodlands.

The uppermost part of the pollen record (zone D8, Fig. 6) shows increasing afforestation due to higher percentages of Corylus, Carpinus betulus, Fagus and deciduous species of Quercus. This phase, centred around a modelled age of 750-700 yrs cal BC, experienced the decline of pasture indicators and cereal fields, mirrored by decreasing concentrations of all P forms. In this context, the coeval increase of charcoal concentration and coprophilous spores is intriguing and requires discussion. Palaeoecological and pedochemical data seem to point to a phase of land abandonment, corroborated by the archaeological record, which speaks for settlement decline in the 8th-6th century вс before the development of the Celtic centre on the Bergamo Hill (Poggiani Keller 2016). Further development of our research is needed to clarify this issue.

\section{Biased pollen spectra}

Zones D2 and D4 are dominated by pine pollen, yielding no or few indicators of anthropogenic habitats, limited concentrations of microscopic charcoal and nutrients, and low $\mathrm{C} / \mathrm{N}$. Pollen preservation is scarce in both zones. We interpret such features as the result of accumulation of (older?) sediments with a pollen signature different from that of the adjacent D1-D3-D5 zones. Pine and Cichorioideae pollen is the most resistant to selective deterioration, both in experimental plots (Havinga 1984) and in past contexts (Bottema
1975; Zangger et al. 2017). Pine pollen, in particular, contains higher percentages of sporopollenin (Traverse 2007). Sediments in zones D2 and D4 could have been deliberately concentrated on the site by humans to level uneven surfaces for farming purposes or they might be the result of massive sheet flows from the nearby gentle slopes, focussing weathered mud into the pond (Ravazzi et al. 2020). See also the curve of selective degradation (pines + Cichorioideae) reported in Fig. 9.

\section{Biodiversity estimates and PCA ordination of biological variables}

The curve of rarefaction-based estimate of richness (Fig. 6) is substantially stable in zones D3-D5 to D8, with a mean number of 39 identified pollen types. This value drops to 18 in zones D2 and D4, due to the overrepresentation of a single type (Pinus sylvestris/mugo) quickly saturating the pollen sums. The Dominance index records a major shift towards values closer to 1 in zone D2, indicating that one taxon/ few taxa dominate the pollen spectra. As for the Shannon diversity index, lower values correspond to zones D2 and D4 (communities with one/few taxa with high values) while values of 2.5-3 characterize all the other pollen zones.

The Principal Component Analysis plot in Fig. 8 identifies the relationships between species recognized in the palaeoecological record. PCA axis 1 and 2 explain ca. 60\% of the total variance nested in pollen data. Samples from zones D2 and D4, with an overall abundance of pine pollen, are clearly separated from all other samples and occupy the right portion of the plot. Samples from zones D3 and D5 are intermixed and located on the left side of the plot with many

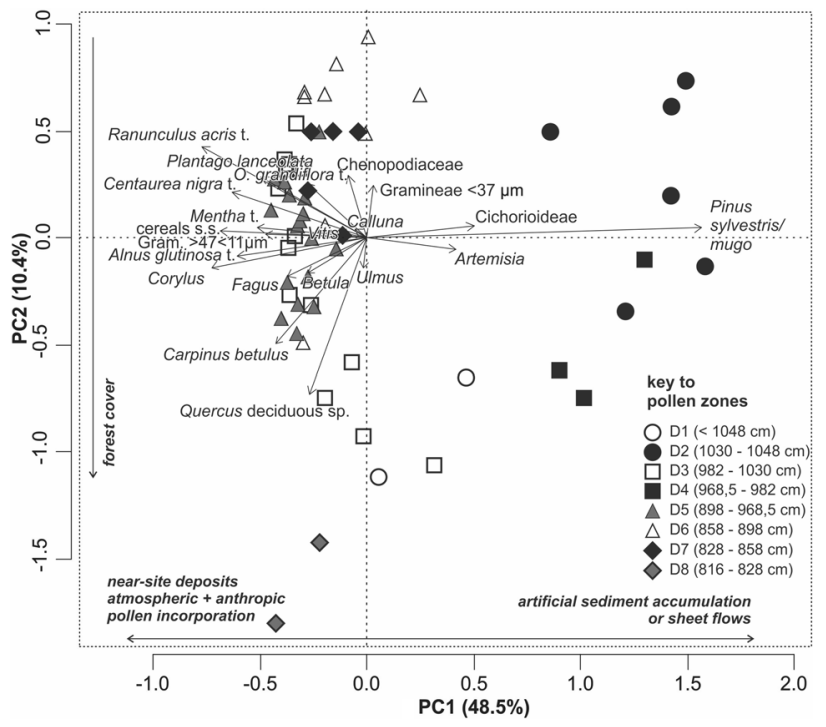

Fig. 8 Principal Component Analysis plot obtained for the Cathedral main core data 


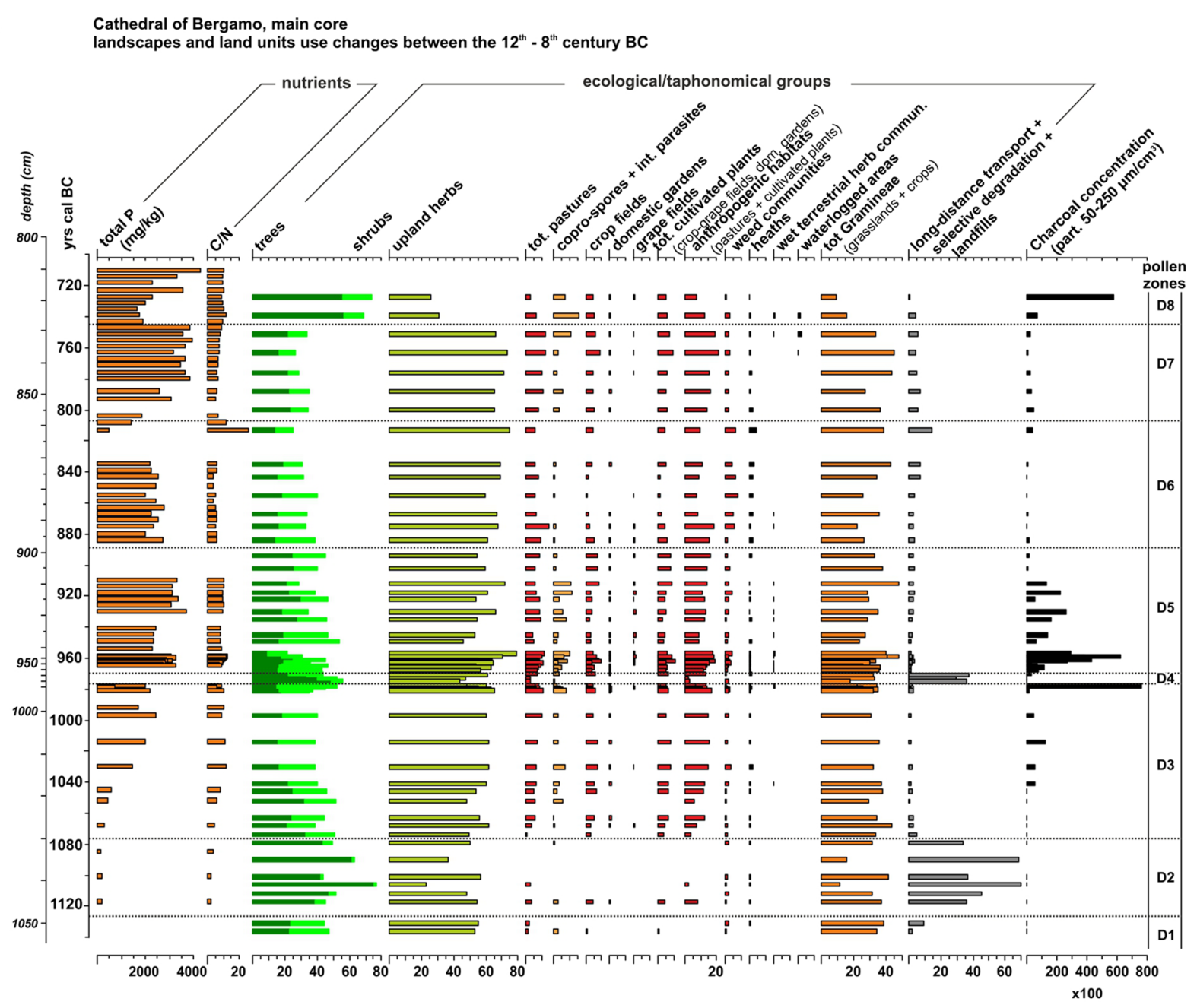

Fig. 9 Changes in quantitative ecological proxies in the high-resolution record of the Cathedral main core, from the Final Bronze Age to the Early Iron Age

herb types. Samples from zone D6 and D7 stay in the upper part of the plot, next to one end of PCA axis 2, which can be related to woody - herb cover. The opposite end of PCA axis 2 is occupied by samples from zone D8.

\section{A detailed view of landscape and land use changes}

The record from the Cathedral main core enables a detailed discussion of palaeoenvironments and land use changes between the 12th-8th century вС (Final Bronze to the Early Iron Ages) (Fig. 9).

In the second half of the 12th century BC woody cover and fire activity on the Bergamo Hill were limited. Pastures, animal husbandry and crop fields are documented. After a phase of land reorganization in the 11th century BC (pollen types diagnostic of secondary non-atmospheric deposition and degradation), between the 11th and the 8th century $\mathrm{BC}$ (ca. 1050-740 BC) the Bergamo Hill reached a high point in the development of anthropogenic habitats, as defined in Table 3, with:

(a) Three distinct phases of expansion of crop fields, set between 1060-960 вс, 910-880 вС and 840-760 вс, largely coeval with expansion of pastures;

(b) Development of ruderal and nitrophilous habitats documented by weed expansion between $880-810$ BC, during a period of minima of crop fields;

(c) Livestock husbandry seems to be well developed between 1050-910 BC and 780-750 BC;

(d) A phase of maximum fire activity between 1040-910 $\mathrm{BC}$

(e) Cultivation of Vitis on the Bergamo Hill is attested between the 10th-8th century вС (980-730 вС), confirmed by a record of pip fragments dated to $830 \mathrm{BC}$ in the trench $\mathrm{C}$ of the Cathedral (see 'Fruits and seeds from the Cathedral trench C'). Micro- and macrobotan- 
ical data from the Bergamo Hilltop indicate grapevine cultivation in the southern Alpine fringe four centuries before the Etruscan trade in the 6th century BC (Sassatelli and Govi 2014; Castellano et al. 2017);

(f) A phase of (secondary?) heath development, indicated by pollen of Calluna and spores of Pteridium aquilinum, during the 9th century вС (zone D6), after the fire phase documented in the 10th century BC (zone D5). Heaths might also reflect the long history of grazing of the previous centuries.

By the 8th century вс palaeoecological data suggest increasing woody cover, particularly favouring Carpinus betulus, Corylus and deciduous species of Quercus. Total P concentration halved. Diagnostic pollen types for pastures and crop fields decrease, charcoal concentration in sediments largely increases (burning of previously productive areas?). Sordaria, Arnium and Trichuris increase; this might be an indication of wild animals grazing in abandoned areas (wild boar cecum intestine hosts Trichuris: Taylor et al. 2016; cervids, roe deer and rabbit droppings host Arnium and Sordaria: Lundqvist 1972; Doveri 2011) and/or wild pasturing of domesticated animals like pigs in woodlands.

The PCA plot in Fig. 10 describes the relationships between environmental parameters and ecological/ethnographical groups. PCA axis 1 and 2 explain $42 \%$ of the total variance nested in the data. Axis 1 distinguishes samples with the highest development of anthropogenic habitats belonging to zones D3 and D5, and samples with a larger representation of ruderals, invasive plants and secondary plant communities (zone D6). Vectors of $\mathrm{P}$ concentrations are located next to pastures and to charcoal concentration, the latter suggesting that a high input of $\mathrm{P}$ might come from ashes. Among $\mathrm{P}$ forms, the vector of organic $\mathrm{P}$ is located closer to coprophilous spores and parasites, underlying the similar trends in those curves in the palaeoecological record.

\section{Fruits and seeds from the Cathedral trench C}

\section{General overview}

The plant macroremains recovered in the five studied samples from the Cathedral trench C (site 4 in Fig. 1b) are listed in ESM 2 and some examples shown in Fig. 7. Samples date to the 9th-7th century вс (Table 2, dates Ub 40936 to 40939) and correspond to pollen zone D7-D8 of the Cathedral main core microbotanical record. These layers are interpreted as dumping deposits (Ravazzi et al. 2020).

Overall, 845 plant remains were identified, representing 42 taxa. Apart from Sambucus ebulus (dwarf elder) and Lemna minor (duckweed) diaspores, all the remains were preserved through charring. Whether the preservation of

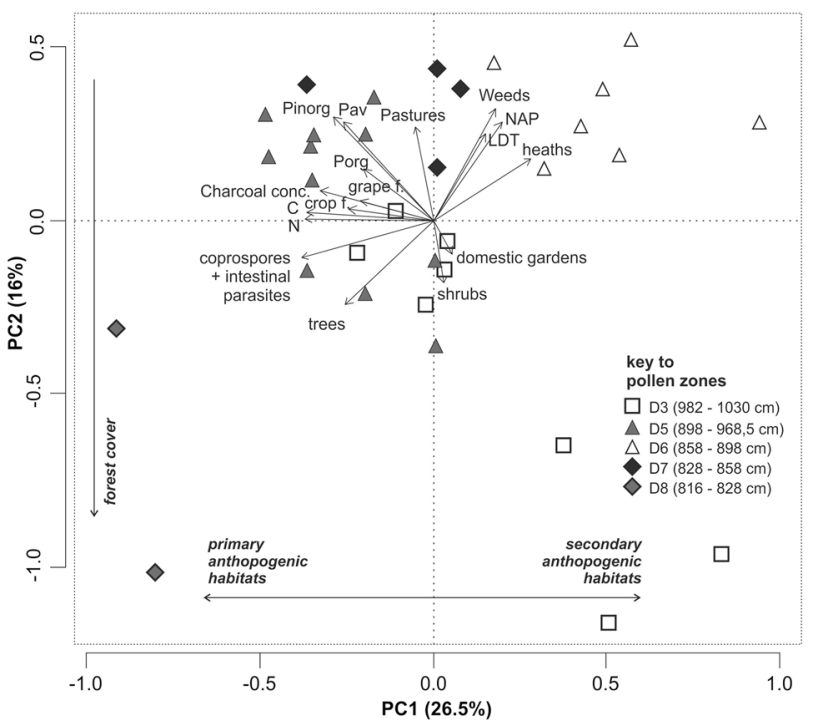

Fig. 10 Principal Component Analysis plot obtained for the Cathedral main core data to explore the relationships between environmental parameters and ecological/ethnographical groups

Sambucus ebulus endocarps may be explained by its strong resistance to decomposition, the antiquity of the duckweed find remains doubtful. The density of remains within the samples varies between 100-519 items/l, with an average of 203.6 items/l. The carpological assemblage is composed of cultivated plants, weeds, ruderals, plants from grassland, as well as a few remains from woodland habitats.

\section{The crop spectrum}

The crop spectrum shows a high diversity with the dominance of cereals (39\% of the remains of economic plants, Fig. 11a). As many as seven cereal cultivars have been identified: barley (Hordeum vulgare), einkorn (Triticum monococcum), emmer ( $T$. dicoccum), spelt ( $T$. spelta), the 'new' glume wheat (T. cf. timopheevi), broomcorn millet (Panicum miliaceum), and foxtail millet / green foxtail (Setaria italica / viridis). The high number of remains is essentially due to the large amount of millet caryopses (more than $60 \%$ of cereal remains). Barley and wheats are represented by few remains of chaff and grains. Regarding the 'new' glume wheat a single spikelet fork was found documenting the persistence of this cultivar in the Early Iron Age in Northern Italy.

The crop assemblage also comprises several pulses: lentil (Lens culinaris), common pea (Pisum sativum), broad bean (Vicia faba var. minor), and possible common vetch ( $V$. cf. sativa). Despite the low amount of pulses remains, lentil is quantitatively the most significant and ubiquitous species. Vitis vinifera (grapevine) finds consist of two pip fragments retrieved in one sample. 


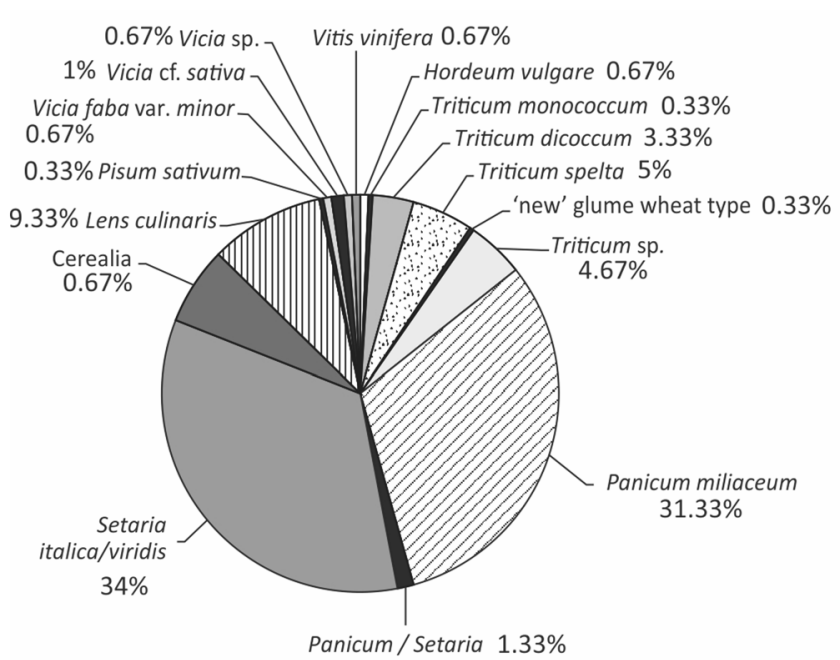

A

(n. remains $=300$ )

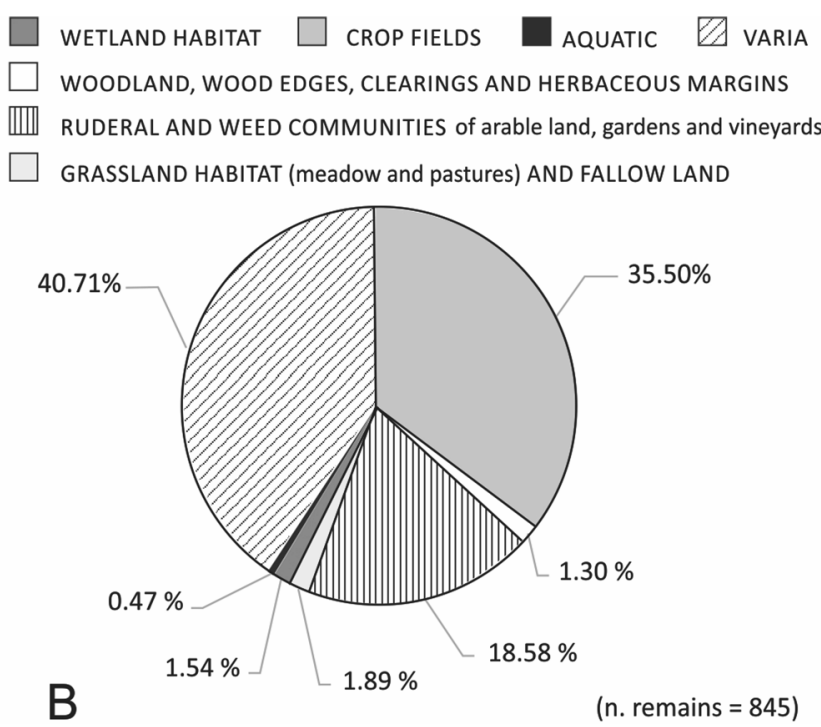

Fig. 11 Plant macrofossil from Cathedral trench C samples: a proportions of cultivated taxa remains; $\mathbf{b}$ proportions of number of remains in each ecological /ethnographical group

\section{Weeds and ruderals}

Apart from a few fragments of hazel nutshell and acorn, all the identified wild species belong to herbaceous taxa mainly of open habitats more or less intensively affected by human activities (Fig. 11b). Plants of weed communities and of ruderal habitats are documented by 12 taxa. Typical winter crop weeds, except for Fallopia convolvulus, are missing whereas summer crop weeds as well as weeds of gardens or hoed fields appeared to be more widely represented in the plant assemblage, e.g. Digitaria sanguinalis (hairy fingergrass, see 'Indicator species of land use with special reference to zoochorous dispersal'), Sherardia arvensis, Solanum cf. nigrum and Chenopodium album. Some of these species might have also grown on disturbed areas or wasteland connected to the settlement.

Some of the perennial ruderal species such as Verbena officinalis and Sambucus ebulus favour soils rich in nutrients - nitrogen and phosphorus released by the decomposition of organic material likely accumulated by man as a consequence of dumping organic waste of different origin as well as by animal stalling. In these ruderal habitats, S. ebulus is an invasive weed forming dense clonal stands on dumping and middens (Eliáš 2007).

\section{Secondary grasslands}

A fair number of wild herbaceous taxa have to be ascribed to secondary grasslands with a variable level of human pressure, discriminated by the different degree of soil humidity. Plant species favouring wet and deep mud as a living substrate might grow in depressed areas with poor drainage, as well as in proximity to springs or pond margins, e.g. Epilobium palustre, Polygonum lapathifolium. On the other hand, finds of Hieracium cf. pilosella indicate dry grasslands, suffering from water deficit in the summer season, developed on thin rocky soils covering the steep slopes stripped of forest vegetation and affected by animal husbandry, frequently overgrazing (see also 'Indicator species of land use with special reference to zoochorous dispersal' - Asphodelus, Orlaya). Species belonging to xerothermal communities, like Silene cf. otites (see Fig. 12g), tolerating heavy water stress, testify to xerothermic tall grasslands, especially those developed on warm southern exposed slopes on rocky substrates or on shallow calcareous or base-rich soils enriched with gravels. These habitats are partly of anthropogenic origin, being affected by livestock grazing. Leucanthemum vulgare, P. lanceolata and Rumex acetosella account for pastures and/or meadows of intermediate conditions of soil humidity, depth and reaction.

The larger number of grassland plants in the wild plant spectrum indicates a high proportion of open habitats in the landscape surrounding the settlement, outlining a mosaic of small patches of secondary grasslands. As there is no clear evidence for haymaking, we might assume that the recorded grassland taxa might have reached the settlement via livestock or intensive overland run-off, or they might have grown on arable fields as remnants of a former fallow phase. 

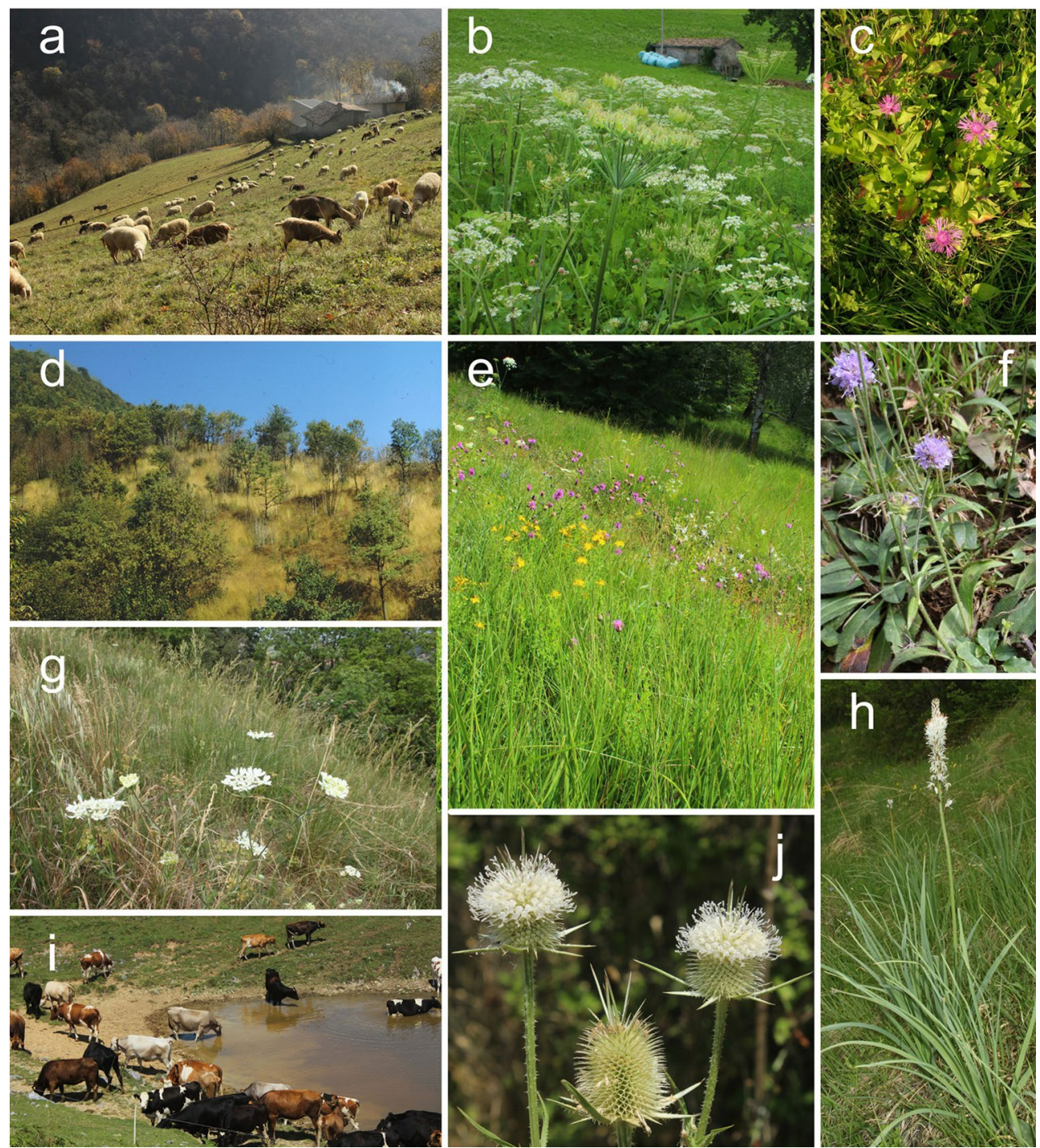

Fig. 12 Traditional land use, pollen indicator species and their habitats in the grassland vegetation of the low mountain belt of the Bergamo Alps. The habitat of Dipsacus laciniatus is taken from a Balkan example. a Manured and once mowed hay meadow, Avenula pubescens-Centaurea nigrescens-type. C. nigrescens characterizes the late summer phenological phase, in the past mowed in late August. The picture shows the early spring grazing by transhumant herds, before the onset of tall grasses (Premolo, Bergamo Alps). b Early summer phenological phase Heracleum sphondylium in an extensive area of basiphilous hay meadows on nutrient-enriched alfisols (M. Farno, Bergamo Alps). Rolls of hay can be seen in the background, near a hut. c Centaurea nigrescens flowering and providing forage still in October (S. Gregorio, Bergamo Alps). d Typical Molinia arundinacea-Betula pendula phase in the post-fire succession of an oak woodland (Quercus pubescens), 3 years after the last fire event (Nese, Bergamo Alps). This successional community is characteris- tic on deep clay soils on calcareous flysch bedrock and provides an optimum for Succisa pratensis (see Fig. 11f). e Tall-herb mesophytic grassland rich in Molinia, Anthericum ramosum (white flowers) and Centaurea scabiosa (pink inflorescences) in Ostrya-Corylus open woodlands, 15 years after fire suppression (M. Podona, Bergamo Alps). f Succisa pratensis flowering in an open oak woodland (M. Bo, Bergamo Alps). g Chrysopogon grillus-Bromus erectus dry grasslands occupying sunny slopes on leached soils. The picture shows a community still grazed by sheep and horses, with umbels of Orlaya grandiflora and occurrences of Silene otites (Desenzano del Garda, Garda glacial amphitheatre). h Asphodelus albus flowering in a residual population on a slope regularly burnt until the 1970s, now being invaded by forest (M. Podona, Bergamo Alps). i Cattle on the clayey margin of a watering pond (M. Farno, Bergamo Alps). j Dipsacus laciniatus, flowering in a Dipsacaceae-rich overgrazed phrygana (Valbica, East Bulgaria) 


\section{Discussion}

\section{Indicator species of land use with special reference to zoochorous dispersal}

In this section we discuss the palaeoecology and the modern ecology of selected plant taxa, along with a coprophilous fungus and an intestinal parasite, to predict synanthropic habitats and/or specific land uses. The indicator value is discussed in view of multiple optima in several habitats controlled by the traditional land use of the Bergamo Forealps. We consider soil properties, fire ecology, and animal and plant husbandry.

Anthericum ramosum: the pollen record of this tall herb, covering quasi-continuously the 300 year long record of the Cathedral main core (it occurs in 18 samples) is unprecedented in the European palynological record. The specific identification of a single pollen grain is diagnosed by its smaller size compared to the congeneric $A$. liliago (Beug 2004). Both species are widespread in the modern grassland-to-forest fringe vegetation of the Bergamo mountains, but all the fossil pollen grains detected could be assigned to A. ramosum. This excludes the habitats of highly acidic heaths and clearings (A. liliago) and points instead to dry herb forest fringes (synecological alliance-Geranion sanguinei); mesic-dry grasslands (alliance Mesobromion, Fig. 12e); alkaline, tall-herb, dry grasslands (class-Seslerietea variae) or seasonally wet grassland (order Molinetalia) (Oberdorfer 1983; Ravazzi 1992; Feoli Chiapella and Poldini 1993; Verde et al. 2010). We consider that this plant was widespread in habitats perhaps mowed but not manured. The traditional pastoralism in the Bergamo Forealps still in the mid 19th century provides an ethnographic example of the Anthericum-rich grassland management, grazed only in spring by transhumant sheep, mowed in summer ("fieno magro "i.e. poor hay) and burnt in winter. If we assume mowing for the Late Bronze Age Bergamo, then hay may have transported pollen, thus enhancing its fossil record. Frequent winter fires may also enhance this plant benefiting from its life form, like other geophytes (see below - Asphodelus).

Asphodelus albus-type: one single pollen grain found in the Cathedral main core, zone D6, suggests the proximity of this plant to the sedimentation site. This perennial herb geophyte is adapted to winter fire (Le Houerou 1973) and can become invasive on rocky substrates and, remarkably, on rocky paddocks due to overgrazing: its leaves regenerate quickly after fires and are unpalatable. Furthermore, wild-boar rooting increases the size and the nutrient content of this geophyte (Palacio et al. 2013). Today in the whole Bergamo Forealps this plant is very rare, small populations persisting on rocky grasslands (Fig. 12h) acting as a refugial habitat after forest progression following fire suppression (field observation by the authors). Suitable habitats for Final Bronze Age Bergamo could be envisaged on limestone outcrops, which were reconstructed as being nearby the site of the Cathedral main core (see palaeoenvironmental reconstruction in Ravazzi et al. 2020) and on the southern, steeper side of the Bergamo Hills, prone to soil erosion and denudation (Fig. 1e).

Centaurea nigra-type (Punt and Hoen 2009 $=C$. jaceatype sensu Beug 2004): the abundant and continuous record of this type (it occurs in 51 samples, mean value $3.8 \%$ ) in the 300 year long record of the Cathedral main core points to a persistent habitat on the Bergamo Hill and suggests a specific activity. Although this pollen type includes several native species of the Bergamo Hills (Federici 2015, Pignatti 2017-2018), the only one reaching high plant cover and high pollen production in the low mountain belt is Centaurea nigrescens Willd. (=C. jacea ssp. nigrescens [Willd.] Celak; C. dubia Suter ssp. nigrescens [Wiild.] Hayek). This species (Fig. 12c) is ecologically similar to the common knapweed (C. nigra L., see Stace 2010) in meadows of West Europe. Both species are adapted to summer mowing in summer-wet climates; indeed, they dominate the summer phenological phase in low altitude permanent meadows managed by fertilization and mowing (notably in the association Centaureo dubio-Arrhenatheretum, see Verde et al. 2010; Pignatti 2017-2018). In a similar British community, C. nigra L. provides more than $20 \%$ of hay biomass and its pollen is a quantitative indicator, being second to grasses for pollen production (Greig 1984). Interestingly, airborne dispersibility of Centaurea pollen is moderate, and pollen percentages are higher in hay-transported pollen (Greig 1984). Furthermore, the pollen proportions between cereals, grasses and knapweeds recorded in the Cathedral main core (4:28:2) are very stable throughout the whole record and very unlikely for an airborne deposition from a mosaic of pastures, cereal fields and ruderal areas only. Moreover, there is no match with an airborne pollen image obtained for reconstructed distributions of land units (Sect. 6 in Ravazzi et al. 2020 for details). These arguments indeed provide support for a pollen sedimentation model including components other than airborne (see 'Pollen deposition model'), i.e. a pollen component transported by animals and/or by hay.

Dipsacus fullonum-group: the quasi-continuous record of the heavy, echinate and large pollen of teasel, Dipsacus fullonum-group, in the 300 year long record of the Cathedral main core (occurring in 29 samples, mean value $=0.4 \%$ ) points to a persistent habitat on the Bergamo Hill and an animal pollen dispersal, or to a specific activity. The pollen type includes D. laciniatus (Fig. 12j) and D. fullonum and its domesticated form D. sativus (Darwin 1859; Clarke and Jones 1981; Ryder 1994). Overall, these three species display a native Pontic range (Velarque 1985) and today are 
noxious, invasive weeds in the New World (Rector et al. 2006). The three Pontic species are known to occupy the same habitat as weeds in ruderal fields in South Germany (Oberdorfer 1983). We directly observed Dipsacus in overgrazed habitats, i.e. the gravelly alluvial plain of the Brembo River a few km south of Bergamo (Fig. 1b) on pebbly fluviatile bars periodically visited by flocks. We also report extensive plant populations in the Bulgarian overgrazed karstic phrygana (Fig. 12j). As early as in the Middle Age, Dipsacus species were cultivated to be used in carding wool fibres (Ryder 1994); Andrieu-Ponel et al. 2000; Gleba 2008). Wool finds in the Middle Bronze Age pile dwelling culture close to Bergamo (site Valle delle Paiole: Poggiani Keller 2003; Bazzanella 2012) suggest that wool processing was likely known in Bronze Age Bergamo. The few textile processing tools so far known from the presumed Final Bronze Age Bergamo (Poggiani Keller and Rondini 2019) may relate either to wool or flax. Unfortunately, we yet have no evidence for contemporary use of Dipsacus. Research on quantitative wool fibres occurrence in the studied laminated sediments of Bergamo, and quantitative correlation analysis with the pollen record of the Dipsacus fullonum-group, are needed to clarify this crucial issue. For the time being, it may be envisaged that Dipsacus was actively dispersed by sheep and goats on the Bergamo Hill thus becoming an important weed in overgrazed ruderal areas, on top of ditches, and on rocky slopes. These habitats provide a favourable environmental background for its use by shepherds.

Digitaria sanguinalis (caryopsis): the occurrence of a large number of caryopses of hairy finger-grass points to the presence of ruderal fields on heavy clay-loam soils with a reaction from neutral to acid and moist to slightly dry conditions (Behrendt and Hanf 1979; Hilty 2014-2019). This fits the soil properties of natural soils evolved on the Bergamo Hill parent material, a sandstone flysch, with a low saturation of the exchange complex (Bonalumi et al. 1992; Ravazzi et al. 2020). D. sanguinalis is a strong competitor and spreads aggressively as it smothers other weeds colonizing large patches. It could have played a role in providing grazing for animals.

Heracleum sphondylium-type: several occurrences of these very distinctive pollen grains point to the presence of hogweed plants nearby the sedimentation site. H. sphondylium, the only species in the genus native in the low mountain modern flora of the Bergamo Forealps Pignatti (2017-2018), is a nitrophilous plant with a distinctive pollen production in mowed and manured meadows (Fig. 12b; Greig 1984; Sheppard 1991). Although this species may occur in other disturbed, nutrient-rich ruderal habitats (Oberdorfer 1983), we consider our fossil pollen record as evidence of manured and grazed meadows in the vicinity, also suggested by the abundance of Centaurea nigra-type pollen. This important forager plant is well known to the cattle herders of the Bergamo Forealps (being given the local name purselàghe) because of its wide elevation range in manured meadows (300 to 2,200 m a.s.l.) and nutrient-rich hay (Dietl 1982; Sheppard 1991) which promotes milk production (interviews of cattle herders by the authors).

Linum usitatissimum-type: given its self-pollination syndrome and large pollen grains, pollen dispersal is limited. Therefore, the three pollen grains identified in the laminated sediments from the Cathedral main core may suggest either flax cultivation or retting (Viklund 2011). Bronze Age cultivation in North Italy is largely documented by flax capsules, seeds, fibres and pollen in the pile-dwelling culture (Arpenti et al. 2004; Perego 2017; Gleba and Baioni 2018).

Orlaya grandiflora-type: the pollen record of white lace flower covers the 300 year long record of the Cathedral main core continuously (it occurs in 38 samples), extending up into the Early Iron Age. More rarely, pollen occurs in the Domus dei Bragagnoli trench C sequence. As remarked by Perego et al. (2011) and Rösch (2018), persistently high pollen values of this plant suggest overgrazed dry fields and intensive, free range growing livestock husbandry in open woodlands, which is likely the case for the Bergamo Hill in the Final Bronze Age. On the other hand, sporadic grains may reflect occurrences in secondary but low-human pressure xerophilous grasslands and forest fringes, as observed today in the sub-mediterranean low mountain belt in the Garda region (Figs. 1b and 12g), just $50 \mathrm{~km}$ east of Bergamo (Perego et al. 2011).

Succisa pratensis-type: there are several occurrences of this monospecific type in zones D3 and D5. S. pratensis grows in wet mesophytic tall-herb grasslands once mowed and sparsely manured by ovicaprine wild pasturing (Molinia-dominated grasslands, Fig. 12e) at the fringe of open oak woodlands (Fig. 12d; Oberdorfer 1983; Ravazzi 1992; see ESM 3).

Verbena officinalis-type: pollen grains of common vervain occur in only two samples of the Cathedral main core record, and four fruits in a near-site sample of the Cathedral trench $\mathrm{C}$. This weed is common in ruderal and weed communities since the Neolithic (Bogaard 2004; Efstratiou et al. 2013).

Trichuris: chitinous eggs of this nematode are frequently found in the Cathedral main core sediments. In most cases, their size falls within the range of that of $T$. trichiura (intestinal parasite of man) and T. suis (pigs), which are not distinguishable. No larger eggs were found that could be referred to $T$. ovis (cattle, sheep, goats) (Brinkkemper and van Haaster 2012). Smaller eggs (larger diameter $<35 \mu \mathrm{m}$ ) also occur in the analysed samples and could not be assigned to a specific host.

Podospora: spores of this genus frequently occur in the Cathedral main core record along with spores of other coprophilous fungi and can be identified by their size (larger 
diameter $>40 \mu \mathrm{m}$ ), the presence of a subapical pore and an opposite flat end with a short bulge. Species belonging to this genus are predominantly coprophilous, very rarely herbicolous-terricolous (Lundqvist 1972). Cow dung, followed by horse and rabbit, is the preferred substrate. The limited dispersibility of these spores makes them a marker for the presence of cattle next to the sedimentation basin (Fig. 12i).

\section{Coprophilous spores as a proxy for husbandry in Bronze Age Bergamo}

Coprophilous spores and intestinal parasites can be used to constrain phases of husbandry in a stratigraphic record even in the absence of archaeological documentation.

The high-resolution record from the Cathedral main core documents a rich and diverse list of coprophilous spores (see 'The Cathedral main core: a high-resolution microbotanical and pedochemical archive from the 12th to the 8th century BC') along with eggs of whipworm (Trichuris) occurring in most of the analysed samples. The available literature on these microscopic remains provides hints on their preferred growing substrates and thus on domesticated animals occurring on the Bergamo Hill from the 12th to the 7th century BC. Podospora and Cercophora grow preponderantly on cow dung (Lundqvist 1972). Sporormiella, an exclusive dunginhabitant (Davis 1987), grows both on cow and sheep dung (Etienne et al. 2013). Sheep droppings seem to be one of the main substrates for the fungus Arnium, along with rabbit and horse droppings, the latter being the preferred substrate for Sordaria. The most common species of this genus (S. fimicola) is a cellulose eater, with a strong affinity for the poorly digested vegetal matter occurring in horse dung (Lundqvist 1972). A certain preference for horse dung is also documented for Apiosordaria: this genus nevertheless occurs on dog, fox and hen droppings (Lundqvist 1972). Delitschia is described as a dung-inhabitant genus, rarely lignicolous: its preferred substrates are cervid and rabbit dung (Bell 1983). As for Trichuris, eggs might be assigned either to Trichuris trichiura or T. suis. In synthesis, coprophilous spores indicate the presence of cows, sheep and horses on the Bergamo hilltop between the 12th-7th century BC, accompanied by pigs.

\section{Practices predicted by plant and biogeochemical indicators: a summary}

Several activities, documented throughout the Final Bronze Age in Bergamo by pollen of indicator plants, coprophilous spores and parasites, are listed here as a synthesis from previous sections:

(i) Extensive and diversified cereal cropping was practiced on the hilltop; (ii) Flax cultivation is circumstantiated; its processing (e.g. retting) is only hypothetical;

(iii) Grapevine cultivation is testified by pollen abundance and the occurrence of pips, though the latter evidence comes from a later phase (8th-7th century $\mathrm{BC}$ ); despite this, there is no evidence for wine production;

(iv) Animal stalling in proximity of a watering pond for cattle and pigs, as suggested by sedimentological evidence, the continuous record of Podospora and Trichuris, the need for water of those animals, and the high concentrations of nutrients derived from animal droppings.

(v) Free range raising of pigs and wild boars in open woodlands may be indicated by proxy changes in the uppermost part of the record (zone D8, see 'The Cathedral main core: a high-resolution microbotanical and pedochemical archive from the 12th to the 8th century BC'). There we observed an expansion of woodlands, coupled by an abundance of Trichuris (see its ecological preferences in 'A detailed view of landscape and land use changes') that suggests affinity with domesticated and/or wild pigs. Conversely, declining nutrient concentrations can be related to loss of nutrients due to reduced numbers of cattle, which would otherwise have produced large amounts of nutrientrich faeces.

The occurrences of Orlaya and a find of Asphodelus might also suggest this practice in an earlier time span in the Final Bronze Age.

(vi) Haymaking. The abundance of Centaurea nigra-type pollen, its continuity throughout the record and proportions to grass and cereal pollen are hints of the development of mowed meadows in land use units in Final Bronze Age Bergamo. Other pollen indicators (see Heracleum sphondylium-type) corroborate this suggestion, together with the abundance of grassland species in fruits and seeds (see 'Secondary grasslands') and the summer-wet pedoclimate requirements of summer-mowed ecosystems.

The hypothesis of the carding of wool is suggested but untenable with the data so far collected.

\section{Plant landscapes and human activities on the Bergamo Hill since the 15th century вс: a synthetic view from palaeoecological records}

Landscape and land use changes in the 15th-7th century BC can be summarized as in Fig. 13, where mean percentages of pollen and carpological data diagnostic of ecological/ taphonomical groups (see Table 3 and 'Developing quantitative ecological proxies based on micro- and macrobotanical remains') are shown.

Using the values from the Palazzo del Podestà samples (15th century BC, lowermost histogram) as a sort of baseline, herb communities doubled since the 13th century вС up to the second half of the 8th century $\mathrm{BC}$, coupled with a 


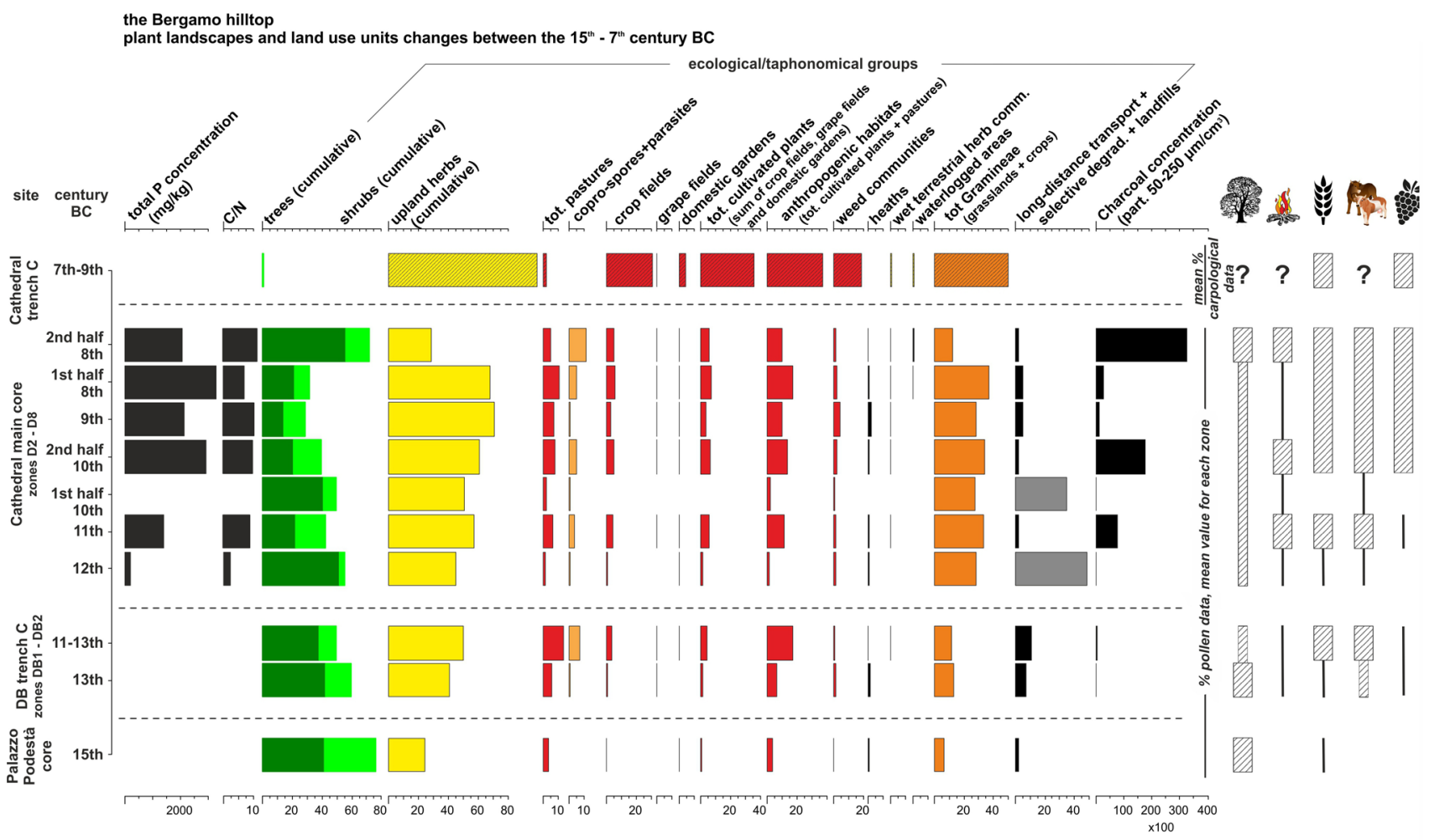

Fig. 13 changes in quantitative ecological proxies between the 15th and the 7th century BC on the Bergamo Hill: an overview based on mean $\%$ values of microbotanical and macrobotanical data from the analysed successions. Symbols on the right side of the figure indicate:

decrease in woody cover. Ecological groups are substantially stable through a period of three centuries, from the 12th to the 8th century вс, suggesting that land units were traditionally dedicated to animal and plant husbandry, this latter not limited to crop cultivation but also to hay making and forage production. Phases of enhanced fire activity can be inferred for the 11th, the second half of the 10th and the second half of the 8 th century вс.

The uppermost histogram in the pollen series for the Cathedral main core, representing pollen zone D8, records overall changes in all proxies related to a major reorganization in land use nearby the sedimentation site - an expansion of woodlands connected to increasing evidence of free range raising of livestock (see 'The Cathedral main core: a high-resolution microbotanical and pedochemical archive from the 12th to the 8th century $\mathrm{BC}$ '). As already noticed, this change took place in the 8th century BC.

The Cathedral trench $\mathrm{C}$ carpological samples (uppermost histogram in Fig. 13) stand out for the scarcity of forest components and dominance of upland herbs $(99.3 \%$ of the analysed remains). The differences between fruits and seeds and the contemporary pollen series reflect dispersal, taphonomy and depositional processes. These issues will hopefully be addressed in a further stage of our research, extent of forest cover, fire activity, crop cultivations, husbandry, vineyards. For a detailed description of the composition of each group, the reader is referred to Table 3

through microbotanical analysis of the same samples as considered for macrobotany.

Available data therefore indicate that herbaceous vegetation supporting animal and crop farming at different levels was widespread on the Bergamo Hill from the 13th to the 7 th century $\mathrm{BC}$, and this feature is unprecedented within the Bronze Age palaeoenvironmental frame of the Alpine fringe.

\section{The mobility of pastoralists, ecological resources and gradients, and the development of Bronze Age settlements on the fringe of the Italian Alps}

Towards the end of the second millennium BC the pattern of territorial occupation in the central sectors of the Po Plain was marked by villages established next to water courses on the plain. The Forealps saw the development of hilltop settlements in dominant positions from which to control the plains and with convenient access to raw material supplies from the valleys (Rondini 2017). This process is emphasised in the physiographic features selected for the control of the territory, and in contemporary development of mining and trade exchanges (Rondini 2017).

However, inferences on settlement strategies should also take into account the availability and variability of biological 
and water resources in space, time and elevation. We maintain that human groups facing the opportunity to establish on the Alpine fringe in the Late-Middle Bronze Age were also farmers, and especially pastoralists. Unfortunately, due to the perishable nature of the agricultural prehistoric record and the limited palaeoecological evidence, farming strategies are easily overlooked.

In this paper, we have demonstrated that farming activity and animal husbandry arose on the Bergamo Hill at the onset of the Final Bronze Age or before. Extensive animal husbandry reached a high point around $1050 \mathrm{BC}$ and persisted uninterruptedly for the following three centuries. This phase is roughly coeval with the first evidence of metal processing in the Bergamo valleys in the Late-Final Bronze Age (Poggiani Keller 2007b). The climax of the Bergamo farming centre also pre-dates the trade-connected urbanization processes at Milano, Como, Bergamo and Brescia (see Fig. 1a and 'Introduction').

The subsistence economy of pastoralist societies is tied to the season of forage availability, which, in mountain regions, is a function of elevation. Hereafter we develop this argument for the Bergamo region recalling local ethnographical examples (Nangeroni 1940; Corti 2004, 2006; Avanzini et al. 2019) and historical documentation, testifying to a remarkable pastoralism in Bergamo already in the Early Middle Ages (Agnelli 1886; Zonca 1998). At that time, transhumant cattle herders were appointed by the episcopus Pergami, i.e. the bishop of Bergamo, and given the epithet of "Bergamini" (Corti 2019).

The fertile plain south of Bergamo was under cropping as early as in the Middle Bronze Age (Zanon in Perego 2017; Perego et al. in press). The mild winter climate of the plain, with warm groundwater emerging at the spring-line around $30 \mathrm{~km}$ south of Bergamo, offered winter resources for animal husbandry (see Fig. 1a, letter "W" for winter; Corti 2019). By the spring onset in early March, shepherds moved to sunny slopes on the Alpine hills. Alternatively, they could spend winter in hill settlements, such as Bergamo. Indeed, pig husbandry and extensive cereal cropping in the Bronze Age Bergamo (see above) speak for permanent settlement. Bergamo provided natural resources for herders and farmers such as drained pastures, hay, biomass for flocks and herds, water (Fortunati and Ghiroldi 2019; Ravazzi et al. 2020) and wood. Furthermore, Bergamo was an ideal base for exploiting the elevational resources in the Forealps and in the inner Alps from late spring to autumn. Ethnographic examples show that herds abandoned the Alpine fringe by end of April and moved north into the main valleys, browsing first the parcels of hay meadows at intermediate elevation (e.g. Fig. 12a) then reaching the higher pastures with substantial water availability in summer (Fig. 1a, letter "S" for summer). Herd itineraries were certainly influenced by the location of intermediate centres (see e.g. Parre in Fig. 1b). However, the location of summer pastures is still unknown and cannot be inferred from ethnographic examples. The Armentarga timberline pasture, $40 \mathrm{~km}$ north of Bergamo (see Fig. 1b), intensively exploited in the Middle Ages, records only limited human impact in the Bronze Age (Furlanetto et al. 2018).

In synthesis, our new palaeoecological evidence, coupled with historical and ethnographic references, suggests that Late-Final Bronze Age farmers exploited the potential of resource availability in space and elevation over the-yet largely unsettled-Alpine fringe. This resulted in substantial forest clearing and burning of low mountain areas (Gobet et al. 2000 and this paper), which were then converted to different types of herb vegetation according to their respective land use. Pastures, hay meadows and managed woodlands dominated over cereal fields in Final Bronze Age Bergamo, in agreement with the preferred dedication to pastoralism of the hills. This was due to shallow soils and the topographic unevenness of bedrock hillscapes (Figs. 1d and e), in turn strongly affected by anthropogenic soil erosion and colluvial processes (Ravazzi et al. 2020). Nevertheless, we postulate that both plains and mountains were exploited in the most convenient season, according to a scheduled cycle controlled by the regional orographic climate rhythm. Settlement development would have been consequently adapted to the proximity of seasonal resources for cereal cropping and pastoralism. The Final Bronze Age settlement increase happened in a phase of thermal conditions favourable for Alpine farming (Tinner et al. 2003; Holzhauser et al. 2005; Ravazzi et al. 2020) and of increasing human population size (De Marinis 2009) in the Final Bronze Age.

The described rangeland pattern emerging for the Bergamo Forealps is constrained by a regional oceanic climate (see 'The Bergamo Forealps-geoecological aspects and land use tradition') and by a specific cultural sequence, not applicable to other biogeographical contexts. Substantial differences are obviously found in mountains under Mediterranean climate and with a specific environmental history. Many cultural and ecoclimatic factors impacting on pastoral strategies operate at a regional scale: location and relevance of pre-existing settlements, human population density, elevational ecological gradients, and grassland primary biomass production under different climate, fire and overgrazing regimes (Perevolotsky and Seligman 1998).

\section{Conclusions}

Our research demonstrates the potential of stratigraphical micro/macrobotanical and pedochemical analysis coupled with a robust chronology in tracing early phases of plant and 
animal husbandry and their subsequent development. Limited amounts of sediments from cores and trenches can successfully yield quantitative information on past landscapes and human ways of life and thus provide major contributions to archaeological disciplines.

The case study presented in this paper is typical for the staged emergence of a prehistoric settlement on a hilltop. As early as the 15 th century $\mathrm{BC}$, the Bergamo hilltop experienced a phase of limited although increasing human impact. We found there first plant indicators of agropastoral activities. Anthropogenic habitats firmly developed between the 12th and the 8th century BC; diagnostic pollen and spore types point to specific activities on the hill, like extensive cereal cropping, flax cultivation or retting, animal husbandry and pastoralism, and free-range livestock raising in woodlands. The hypotheses of wool carding and haymaking are possible but not fully sustainable at the present state of the research. The most significant plant indicators for reconstructing landscape and human activities proved to be pollen of Anthericum ramosum, Asphodelus albus, Centaurea nigra, Dipsacus fullonum-group, Heracleum sphondilium, Linum usitatissimum, Orlaya grandiflora and fruits and seeds of Digitaria sanguinalis, Hieracium pilosella, Silene otites and Vitis vinifera. Between the 8th-7th century вС major changes in land unit usage took place. Further palaeoecological data are necessary to clarify this issue, possibly in conjunction with a careful analysis and evaluation of the existing archaeological record.

Coupled with historical documentation and ethnographical examples, palaeoecological data underlined the importance of natural resources to prehistoric farmers, in agreement with the dedication to farming of the Forealps facing the plain, benefiting from a favourable climate and soil regimes. Even location of settlements may be connected to the seasonal availability of natural resources.

Data comparison and integration among methods and disciplines (stratigraphy, chronology, palaeoecology, archaeology etc.), once we have defined what we want to compare and for what purpose (settlements density and demography, subsistence economies, land use in relation to topography and other environmental parameters, etc.), is the way to promote significant steps forward to a better and fuller understanding of the past.

Acknowledgements We thank Raffaella Poggiani Keller and Maria Fortunati (formerly at Soprintendenza Beni Archeologici Regione Lombardia) and Sergio Chiesa (formerly at CNR) for promoting the palaeoecological investigation of the sediments beneath the ancient city of Bergamo. Stefano Banfi (Univ. Milano Bicocca) is thanked for skilful longitudinal sectioning of the consolidated Cathedral and Palazzo del Podestà cores. Thanks are due to Andrea Tramelli and Paolo Bertuletti for lab preparation of palynological samples, Greta Agazzi and Bernardo Raineri for pedochemical analysis. Stefano Armiraglio (Museo Civico di Scienze Naturali, Brescia) provided his expertise on grassland plant sociology in the Forealps and Stefania Casini (Museo
Civico Archeologico, Bergamo) advised on the archaeological record. Interviews with cattle herders Gioachino Zanoni and Paolo Giudici provided invaluable information on pasture ecology. We thank Manfred Rösch and an anonymous reviewer for constructive comments. This paper, written during the 'smart' working period allowed during the SARS-CoV-2 pandemic, is a contribution to the CNR Research Line DTA.AD001.112.001.

\section{References}

Agnelli G (1886) Del diritto di pascolo nel nostro territorio nel Medio Evo; origine e storia della parola Malghese. Archivio storico per la città e comuni del circondario di Lodi 3-4:54-64

Akeret Ö, Haas JN, Leuzinger U, Jacomet S (1999) Plant macrofossils and pollen in goat/sheep faeces from the Neolithic lake-shore settlement Arbon Bleiche 3, Switzerland. Holocene 9:175-182

Andersen ST (1979) Identification of wild grass and cereal pollen. Danmarks Geologiske Undersøgelse, Arbog 1978:69-92

Andreis C, Cerabolini B (1995) La brughiera briantea: la vegetazione ed il Piano di gestione. In: Gehú J-M (eds), La brughiera briantea: la vegetazione ed il Piano di gestione. Colloques Phytosociologiques 21. Cramer, Berlin, Stuttgart, pp 195-224

Andrieu-Ponel V, Ponel P, Bruneton H, Leveau P, de Beaulieu J-L (2000) Paleoenvironments and cultural landscapes of the last 2000 years reconstructed from pollen and Coleopteran records in the Lower Rhône Valley, southern France. Holocene 10:341-355

Arpenti E, Ravazzi C, Deaddis M (2004) Il Lavagnone di Desenzano del Garda: analisi pollinica e informazioni paleoecologiche sui depositi lacustri durante le prime fasi d'impianto dell'abitato (Antica età del Bronzo). Not Archeol Bergomensi 10:35-54

Atkinson MD (1992) Betula pendula Roth (B. verrucosa Ehrh.) and B. pubescens Ehrh. J Ecol 80:837-870

Avanzini M, Bonoldi A, Gios G, Salvador I (2019) Main drivers of the evolution of grazing in the alpine area of Valli del Leno (Trentino, Northern Italy) during the last two centuries: natural resources, labour and investments. Historia Agraria 78:37-65. https://doi.org/10.26882/histagrar.078e02b

Bazzanella M (2012) Italy Neolithic and Bronze Age. In: Gleba M, Mannering U (eds), Textiles and Textile Production in Europe: From Prehistory to AD 400. Ancient Textiles 11. Oxbow Books, Oxford, pp 203-214

Behrendt S, Hanf M (1979) Grass weeds in world agriculture: Identification in the flowerless state, 1st edn. BASF AG, Ludwigshafen am Rhein

Bell A (1983) Dung Fungi: An illustrated guide to coprophilous fungi in New Zealand. Lubrecht \& Cramer Ltd

Berggren G (1981) Atlas of seeds and small fruits of Northwest-European plant species with morphological descriptions. Part 3: Salicaceae-Cruciferae. Swedish Museum Natural History, Stockholm

Bersezio R, Bini A, Ferliga C, Gelati R (2012) Note Illustrative Della Carta Geologica d'Italia alla Scala 1:50.000 - Foglio 098 Bergamo. Servizio Geologico d'Italia - Regione Lombardia

Beug H-J (2004) Leitfaden der Pollenbestimmung für Mitteleuropa und angrenzende Gebiete. Pfeil, München

Blume H-P, Brümmer GW, Fleige H et al (2016) Scheffer/Schachtschabel Soil Science. Springer, Berlin, Heidelberg

Bogaard A (2004) Neolithic farming in Central Europe: An archeobotanical study of crop husbandry practices. Routledge, Abingdon, Oxon

Bonalumi G, Roncalli W, Vitali G (1992) I suoli dell'hinterland bergamasco. E.R.S.A.L. Progetto "Carta Pedologica", SSR 12, Milano

Bottema S (1975) The interpretation of pollen spectra from prehistoric settlements (with special reference to Liguliflorae). Palaeohistoria 17:17-35 
Brinkkemper O, van Haaster H (2012) Eggs of intestinal parasites whipworm (Trichuris) and mawworm (Ascaris): non-pollen palynomorphs in archaeological samples. Rev Palaeobot Palynol 186:16-21

Cappers RTJ, Bekker RM, Jans JEA (2006) Digitale Zadenatlas van Nederland / Digital Seed Atlas of the Netherlands Groningen Archaeological Studies 4. Barkhuis, Groningen

Casini S, De Marinis RC, Rapi M (2001) L'abitato protostorico dei dintorni di Como. La protostoria in Lombardia, Atti del Convegno di Como. 1:97-140

Castellano L, Ravazzi C, Furlanetto G, Pini R, Saliu F, Lasagni M, Orlandi M, Perego R, Degano I, Valoti F, De Marinis RC, Casini S, Quirino T, Rapi M (2017) Charred honeycombs discovered in Iron Age Northern Italy. A new light on boat beekeeping and bee pollination in pre-modern world. J Archaeol Sci 83:26-40

Chiesa S, Pini R (2008) Lo sviluppo della città e le trasformazioni morfologiche e paleoambientali del Colle di Bergamo. In M. Mencaroni Zoppetti (eds), D'erbe e piante adorno. Per una storia dei giardini a Bergamo, percorsi tra paesaggi e territorio. Ateneo di Scienze, Lettere e Arti di Bergamo, Collana "Studi di Storia della Società, dell'Economia e delle Istituzioni bergamasche, Fondazione per la Storia Economica e Sociale di Bergamo, 3: 127-140

Clarke GCS, Jones MR (1981) The Northwest European pollen flora, Vol 21: Dipsacaceae. Rev Palaeobot Palynol 33:1-25

Colombo C, Miano TM (eds) (2015) Metodi di analisi chimica del suolo, 3 a versione. Società Italiana della Scienza del Suolo (SISS)

Corti M (2004) Süssura de I aalp. Il sistema alpeggio nelle Alpi Lombarde. Museo Usi e Costumi della Gente Trentina 17:31-155

Corti M (2006) Evoluzione delle forme di colonizzazione pastorale nell'area alpina lombarda. Workshop Museo Archeologico Paolo Giovio, Como, 1 Aprile 2006

Corti M (ed) (2019) La transumanza tra storia e presente. Studi sulla transumanza e l'alpeggio, Festival del Pastoralismo, Corna Imagna (Bergamo)

Crespi A, Brunetti M, Lentini G, Maugeri M (2018) 1961-1990 highresolution monthly precipitation climatologies for Italy. Int $\mathbf{J}$ Climatol 38:878-895

Darwin C (1859) The origin of species by means of natural selection or the preservation of favoured races in the struggle for life. Variation under domestication.Murray, London, pp 7-43

Davis OK (1987) Spores of the dung fungus Sporormiella: increased abundance in historic sediments and before Pleistocene megafaunal extinction. Quat Res 28:290-294

De Marinis RC (1999) Towards a relative and absolute chronology of the Bronze Age in Northern Italy. Not Archeol Bergomensi 7:23-100

De Marinis RC (2009) Continuity and discontinuity in Northern Italy from the recent to the final bronze age: A view from North-Western Italy. Sci dell'Antichità Storia Archeol Antropol 15:535-545

De Marinis RC (2014) Correlazioni cronologiche tra Italia nordoccidentale (area della Cultura di Golasecca) e ambiti culturali transalpini e cisalpini dal Bronzo Recente alla fine del VII secolo a.C. Les Celtes et le Nord de l'Italie (Premier et Second Âges du fer). Actes du XXXVIe colloque international de l'A.F.E.A.F. (Vérone, 17-20 mai 2012), 17:17-35

Dietl W (1982) Weeds of pastures and meadows in the European Alps. In: Holzner W, Numata N (eds) Biology and ecology of weeds. Junk, The Hague, pp 375-385

Doveri F (2011) Additions to "Fungi Fimicoli Italici": an update on the occurrence of coprophilous basidiomycetes and ascomycetes in Italy with new records and descriptions. Mycosphere 2:331-427

Edwards KJ (1991) Using space in cultural palynology: the value of the off-site pollen record. In: Harris DR, Thomas KD (eds) Modelling ecological Change: prespectives from neoecology, palaeoecology and environmental archaeology. University College London, Institute of Archaeology, London

Eliáš P (2007) Rhizome size structure and belowground biomass of Sambucus ebulus L. populations a monodominated plant community. Ekológia (Bratislava) 26:429-436

Ellenberg H (1988) Vegetation Ecology of Central Europe. Cambridge University Press, New York

Efstratiou N, Karetsou A, Ntinou M (eds) (2013) The Neolithic settlement of Knossos in Crete: New evidence for the early occupation of Crete and the Aegean Islands. INSTAP Academic Press, Philadelphia

Etiégni L, Campbell AG (1991) Physical and chemical characteristics of wood ash. Bioresour Technol 37:173-178

Etienne D, Wilhelm B, Sabatier P, Reyss JL, Arnaud F (2013) Influence of sample location and livestock numbers on Sporormiella concentrations and accumulation rates in surface sediments of Lake Allos, French Alps. J Palaeolimnol 49:117-127

Federici G (ed) (2015) Flora spontanea della città di Bergamo. FAB / Gruppo Flora Alpina Bergamasca, Bergamo

Feoli Chiapella L, Poldini L (1993) Prati e pascoli del Friuli (NE Italia) su substrati basici. Stud Geobot 13:3-140

Figueiredo M, Fernando A, Martins G, Freitas J, Judas F, Figueiredo H (2010) Effect of the calcination temperature on the composition and microstructure of hydroxyapatite derived from human and animal bone. Ceram Int. 36:2383-2393

Fortunati M (2012) La città in età romana. In: Fortunati M, Ghiroldi A (eds) Hospitium Comunis Pergami: Scavo archeologico, restauro e valorizzazione di un edificio storico della città. Soprintendenza per i beni archeologici della Lombardi, Milano, pp 57-59

Fortunati M, Ghiroldi A (2019) Il sistema di distribuzione delle acque in Città Alta in età Romana: acquedotti e cisterne. In: Casini S, Fortunati M, Poggiani Keller R (eds) Bergomum: Un colle che divenne città. Lubrina Bramani editore, Bergamo, pp 179-185

Furlanetto G, Ravazzi C, Pini R et al (2018) Holocene vegetation history and quantitative climate reconstructions in a high-elevation oceanic district of the Italian Alps: Evidence for a middle to late Holocene precipitation increase. Quat Sci Rev 200:212-236

Gleba M (2008) Textile Production in Pre-Roman Italy. Ancient Textile Series 4. Oxbow Books, Oxford

Gleba M, Baioni M (2018) New textile find from Lucone di Polpenazze (BS). In: Baioni M, Mangani C, Ruggiero MG (eds) The pile dwellings: investigation, conservation, enhancement. SAP Società Archeologica, Quingentole, pp 260-264

Gobet E, Tinner W, Hubschmid P, Jansen I, Wehrli M, Ammann B, Wick L (2000) Influence of human impact and bedrock differences on the vegetational history of the Insubrian Southern Alps. Veget Hist Archaeobot 9:175-187

Greig J (1984) The palaeoecology of some British hay meadow types. In: van Zeist W, Casparie WA (eds) Plants and Ancient Man: Studies in palaeoethnobotany. Balkema, Rotterdam, pp 213-227

Grimm EC (1987) CONISS: a FORTRAN 77 program for stratigraphically constrained cluster analysis by the method of incremental sum of squares. Comput Geosci 13:13-35

Grimm EC (2004) TGView version 2.0.2. Springfield Illinois State Museum, Research and Collection Center, Springfield

Hammer $\varnothing$, Harper DAT, Ryan PD (2001) PAST: Paleontological Statistics Software Package for Education and Data Analysis. Palaeontol Electron 4:1-9

Havinga AJ (1984) A 20-year experimental investigation into the decay of pollen and spores in various soil types. Pollen Spores 26:541-558

Hilty J (2014-2019) Grasses, Sedges, Rushes, and Non-flowering Plants in Illinois. https://illinoiswildflowers.info/grasses/. Accessed 20 August 2020 
Holzhauser H, Magny M, Zumbühl HJ (2005) Glacier and lake-level variations in west central Europe over the last 3500 years. Holocene 15:789-801

Hosch S, Zibulski P (2003) The influence of inconsistent wet-sieving procedures on the macroremains concentration in waterlogged sediments. J Archaeol Sci 30:849-857

Jacomet S (2006) Bestimmung von Getreidefunden aus archäologischen Ausgrabungen (Identification of cereal remains from archaeological sites), 2nd edn. Universität Basel, Basel, IPNA

Jacquiot C, Trenard Y, Dirol D (1973) Atlas d'Anatomie des Bois des Angiosperms. Centre Technique du Bois, Paris

Joly C, Barillé L, Barreau M, Mancheron A, Visset L (2007) Grain and annulus diameter as criteria for distinguishing pollen grains of cereals from wild grasses. Rev Palaeobot Palynol 146:221-233

Kühn M, Maier U, Herbig C, Ismail-Meyer K, Le Bailly M, Wick L (2013) Methods for the examination of cattle, sheep and goat dung in prehistoric wetland settlements with examples of the sites Alleshausen-Täschenwiesen and Alleshausen-Grundwiesen (around cal 2900 BC) at Lake Federsee, south-west Germany. Environ Archaeol 18:43-57

Le Houerou HN (1973) Fire and vegetation in the Mediterranean Basin. Proceedings Annual Tall Timbers, Fire Ecology Conference (January 1973)

Lucas G (2013) Understanding the archaeological record. Can J Archaeol 37:334-337

Lundqvist N (1972) Nordic Sordariaceae s. lat. Symbolae Botanicae Upsalienses 20. Almqvist \& Wiksells, Stockholm

Martinelli E, Michetti AM, Colombaroli D et al (2017) Climatic and anthropogenic forcing of prehistorical vegetation succession and fire dynamics in the Lago di Como area (N-Italy, Insubria). Quat Sci Rev 161:45-67

Meyer M (1977) Vergleich verschiedener Chrysopogon gryllus-reicher Trockenwiesen des insubrischen Klimabereiches und angrenzender Gebiete. Vegetatio 35:107-114

Moore PD, Webb JA, Collinson ME (1991) Pollen analysis, 2nd edn. Blackwell, Oxford

Nangeroni G (1940) Tipi di alpeggio nelle valli Oróbie occidentali. Riv Geogr Ital 47:174-181

Neef R, Cappers RTJ, Bekker RM (2012) Digital atlas of economic plants in archaeology. Groningen archaeological studies 17. Barkhuis, Groningen

Oberdorfer E (1964) Der insubrische vegetationskomplex, seine struktur und abgrenzung gegen die submediterrane vegetation in oberitalien und in der südschweiz. Beitr Naturk Forsch SüdwDtl 23:141-187

Oberdorfer E (1977) Süddeutsche Pflanzengesellschaft, Teil 1. Fischer, Stuttgart

Oberdorfer E (1983) Pflanzensoziologische Exkursionsflora. Ulmer, Stuttgart

Oksanen J, Blanchet FG, Kindt R et al (2019) Vegan: Community Ecology Package. R package version 2.2-1. https://CRAN.R-proje ct.org/package $=$ vegan

Osman KT (2013) Soils: Principles. Properties and Management, Springer, Dordrecht

Palacio S, Bueno CG, Azorín J, Maestro M, Gómez García D (2013) Wild-boar disturbance increases nutrient and $\mathrm{C}$ stores of geophytes in subalpine grasslands. Am J Bot 100(9):1790-1799

Perego R (2017) Contribution to the development of the Bronze Age plant economy in the surrounding of the Alps: an archaeobotanical case study of two Early and Middle Bronze Age sites in northern Italy (Lake Garda region). PhD Thesis, University of Basel, Basel

Perego R, Badino F, Deaddis M, Ravazzi C, Vallè F, Zanon M (2011) L'origine del paesaggio agro-pastorale in Nord Italia: espansione di Orlaya grandiflora (L.) Hoffm. nella civiltà palafitticola
dell'Età del Bronzo della regione del Garda. Not Archeol Bergomensi 19:161-173

Perego R, Rottoli M, Castiglioni E (in press) Agricoltura e preferenze alimentari durante le età del Bronzo e del Ferro in Lombardia. Atti della LII Riunione Scientifica Preistoria e Protostoria in Lombardia

Perevolotsky A, Seligman N (1998) Role of grazing in mediterranean rangeland ecosystems. Biogeoscience. 48:1007-1017

Pignatti S (2017-2018) Flora d'Italia, Vol 1-4, 2nd edn. Edagricole, Milano

Pini R, Castellano L, Perego R, Ravazzi C, Chiesa S, de Amicis M (2016) Nuovi dati sulla storia ambientale del centro abitato di Bergamo Alta tra la fase arcaica dell'Età del Bronzo e il Medioevo. Stratigrafia, paleoecologia e archeobotanica dei depositi del Palazzo del Podestà (Piazza Vecchia). In: Mencaroni Zoppetti M (ed) Atti dell'Ateneo di Scienze Lettere e Arti di Bergamo, vol 79. Bergamo, Sestante Edizioni, pp 349-371

Poggiani Keller R (2003) Valle delle Paiole. In: Bazzanella M, Mayr A, Moser L, Rast-Eicher A (eds) Textiles: Intrecci e tessuti dalla preistoria europea. Ufficio Beni Archeologici, Trentino

Poggiani Keller R (2007a) L'età del Ferro: Dall'oppidum degli Orobi alla formazione della città sul colle. In: Fortunati M, Poggiani Keller R (eds) Storia economica e sociale di Bergamo: I primi millenni. Dalla preistoria al Medioevo 1. Fondazione per la Storia economica es sociale di Bergamo, Bergamo

Poggiani Keller R (2007b) L'età del Bronzo: Aspetti insediativi e culturali, attività, sepolture e rituali. In: Fortunati M, Poggiani Keller R (eds) Storia economica e sociale di Bergamo: I primi millenni. Dalla preistoria al Medioevo 1. Fondazione per la Storia economica es sociale di Bergamo, Bergamo

Poggiani Keller R (2012) Il primo abitato sul colle: il centro protourbano dei Celti golasecchiani. In: Fortunati M, Ghiroldi A (eds) Hospitium Comunis Pergami: Scavo archeologico, restauro e valorizzazione di un edificio storico della città. Soprintendenza per i beni archeologici della Lombardia, Milano, pp 54-56

Poggiani Keller R (2016) La scelta del sito della prima città. Atti dell'Ateneo Scienze Lettere ed Arti di Bergamo 79:163-173

Poggiani Keller R, Rondini P (2019) Bergamo prima della città Romana. In: Casini S, Fortunati M, Poggiani Keller R (eds) Bergomum: Un colle che divenne città. Lubrina Bramani Editore, Bergamo, pp 191-198

Poldini L, Oriolo G (1994) La vegetazione dei prati da sfalcio e dei pascoli intensivi (Arrhenatheretalia e Poo-Trisetetalia) in Friuli (NE-Italia). Stud Geobot 14:3-48

Punt W, Hoen PP (2009) The Northwest European Pollen Flora, 70: Asteraceae - Asteroideae. Rev Palaeobot Palynol 157:22-183

Punt W, Blackmore S, Clarke GCS, Hoen PP, Stafford PJ (eds) (1976-2009) The Northwest European Pollen Flora, Vol I-IX. Elsevier, Amsterdam

R Core Team (2020) R: A language and environment for statistical computing. R Foundation for Statistical Computing, Vienna, Austria. https://www.r-project.org/index.html

Rasmussen P (1990) Leaf foddering in the earliest Neolithic agriculture. Evidence from Switzerland and Denmark. Acta Archaeol 60:71-86

Ravazzi C (1992) Lineamenti fisionomici, ecologia e fattori edafici della vegetazione di alcuni massicci calcareo-dolomitici delle Prealpi Lombarde. Natura Bresciana 27:11-49

Ravazzi C, Badino F, Castellano L et al (2019) Introduzione allo studio stratigrafico e paleoecologico dei laghi intramorenici del Garda. In: Baioni M, Mangani C, Ruggiero MG (eds) Le Palafitte. Ricerca, Conservazione, Valorizzazione. Collana Palafitte/Palafittes/Pfahlbauten/Pile Dwellings/Palafitte. SAP - Società Archeologica, Quingentole (Mn), pp 167-183

Ravazzi C, Pini R, de Amicis M et al (2020) Paleoecological archives unraveling the early land-use history at the emergence of the 
Bronze Age settlement of Bergamo (Italian Alps). Rev Palaeobot Palynol 276:104-205

Rector BG, Harizanova V, Sforza R, Widmer T, Wiedenmann RN (2006) Prospects for biological control of teasels, Dipsacus spp., a new target in the United States. Biol Control 36:1-14

Reille M (1992-1998) Pollen et spores d'Europe et d'Afrique du nord. Laboratoire de botanique historique et palynologie, Marseille

Reimer PJ, Bard E, Bayliss A et al (2013) INTCAL13 and MARINE13 radiocarbon age calibration curves $0-50,000$ years cal BP. Radiocarbon 55:1,869-1,887

Rizzitano G, Alquati G (1997) Chimica agraria. Edizioni Edagricole, Calderini, Bologna

Rondini P (2017) L'interfaccia orientale della cultura di Golasecca. In: Harari M (ed) Il territorio di Varese in età preistorica e protostorica. Nomos Edizioni, Busto Arsizio, pp 263-289

Rösch M (2018) Evidence for rare crop weeds of the Caucalidion group in Southwestern Germany since the Bronze Age: palaeoecological implications. Veget Hist Archaeobot 27:75-84

Ryder ML (1994) Fascinating Fullonum Circaea 31:23-31

Sassatelli G, Govi E (2014) Etruria on the Po and the Adriatic. In: Turfa JM (ed) The Etruscan World. Routledge, London, pp 281-300

Schiegl S, Lev-Yadun S, Bar-Yosef O, Goresy EI, A, Weiner S, (1994) Siliceous aggregates from prehistoric wood ash: A major component of sediments in Kebara and Hayonim caves (Israel). Isr J Earth Sci 43:267-278

Schweingruber FH (1990) Microscopic wood anatomy: structural variability of stems and twigs in recent and Subfossil Woods from Central Europe, 3rd edn. Swiss Federal Institute for Forest, Snow and Landscape Research, Birmensdorf

Sharpley A, Moyer B (2000) Phosphorous forms in manure and compost and their release during simulated rainfall. J Environ Qual 29:1,462-1,469

Sheppard W (1991) Heracleum sphondylium. J Ecol 79:235-258

Stace C (2010) New Flora of the British Isles, 3rd edn. Cambridge University Press, Cambridge

Stasky E (1982) Advances in Urban Archaeology. In: Schiffer MB (ed) Advances in Archaeological Method and Theory, vol 5. Academic Press. New York, London, pp 97-149

Stockmarr J (1971) Tablets with spores used for absolute pollen analysis. Pollen Spores 13:615-620
Sutter R (1962) Das Caricion austroalpinae, ein neuer insubrisch sudalpiner Seslerietalia-verband. Mitteilungen der OstalpinDinarischen Pflanzensoziologischen Arbeitsgemeinschaft $2: 18-22$

Taylor MA, Coop RL, Wall RL (2016) Veterinary Parasitology. WileyBlackwell, Hoboken

Tinner W, Lotter AF, Ammann B, Conedera M, Hubschmid P, van Leeuwen JFN, Wehrli M (2003) Climatic change and contemporaneous land-use phases north and south of the Alps $2300 \mathrm{BC}$ to 800 AD. Quat Sci Rev 22:1,447-1,460

Traverse A (2007) Paleopalynology, 2nd edn. Springer, Dordrecht

Verde S, Assini S, Andreis C (2010) Le serie di vegetazione della Regione Lombardia. In: Blasi C (ed) La Vegetazione d'Italia. Palombi, Roma, pp 53-81

Viklund K (2011) Flax in Sweden: the archaeobotanical, archaeological and historical evidence. Veget Hist Archaeobot 20:509-515

Wick L, Mohl A (1996) The mid-Holocene extinction of silver fir (Abies alba) in the Southern Alps: A consequence of forest fires? Palaeobotanical records and forest simulations. Veget Hist Archaeobot 15(4):435-444

WRB, IUSS Working Group (2015) World Reference Base for Soil Resources 2014, update 2015. International soil classification system for naming soils and creating legends for soil maps. World Soil Resources Reports No. 106. FAO, Rome

Zangger E, Timpson ME, Yazvenko SB, Kuhnke F, Knauss J (2017) The Pylos Regional Archaeological Project, Part II: landscape evolution and site preservation. In: Davis JL, Bennet J (eds) The Pylos Regional Archaeological Project, a retrospective. Princeton, American School of Classical Studies at Athens, pp 153-234

Zohary D, Hopf M, Weiss E (2012) Domestication of Plants in the Old World: The origin and spread of domesticated plants in southwest Asia. Oxford University Press, Oxford, Europe and the Mediterranean Basin

Zonca A (1998) Gli uomini e le terre dell'Abbazia San Benedetto di Vallalta (secoli XII-XIV). Comune di Bergamo, Civica Biblioteca Angelo Mai, Bergamo, pp 78-86

Publisher's Note Springer Nature remains neutral with regard to jurisdictional claims in published maps and institutional affiliations. 